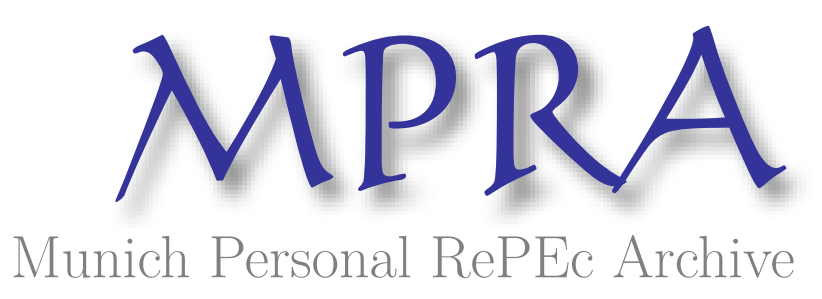

\title{
When an Importer's Protection of IPR Interacts with an Exporter's level of Technology: Comparing the Impacts on the Exports of the North and South
}

Shin, Wpnkyu and Lee, Keun and Park, Walter

2015

Online at https://mpra.ub.uni-muenchen.de/109959/

MPRA Paper No. 109959, posted 29 Sep 2021 07:45 UTC 
Forthcoming in World Economy (2015)

\title{
When an Importer's Protection of IPR Interacts with an Exporter's level of Technology: Comparing the Impacts on the Exports of the North and South
}

\author{
Wonkyu Shin ${ }^{1}$, Keun Lee ${ }^{2}$, and Walter G. Park ${ }^{3 *}$ \\ ${ }^{1}$ Center for International Commerce and Strategy, and Graduate School of International Studies, \\ Seoul National University. E-mail: wkshin@snu.ac.kr \\ ${ }^{2}$ Department of Economics, Seoul National University. E-mail: kenneth@snu.ac.kr \\ ${ }^{3}$ Department of Economics, American University, 4400 Massachusetts Ave. NW Washington, \\ D.C. 20016, USA. E-mail: WGP@ American.edu \\ ${ }^{*}$ Corresponding Author
}

May 2014

\begin{abstract}
Using bilateral trade data of countries from 2000 to 2007, this paper contributes to the empirical literature on the role of intellectual property rights (IPRs) in global trade. The existing literature has focused on how IPRs in the destination country affect exports from a source country. In this paper, we add an additional dimension: the level of technology of the exporting country (LT). This is quite important for distinguishing the impact of IPRs on the exports of developed and developing countries, since the technology levels vary across countries at different stages of development and intellectual property rights better protect exports that are technologically advanced than exports that are imitative and potentially infringing. By factoring in the level of technology (LT), our empirical analysis makes the case that IPRs can act as barrier to exports from the South, especially the rapidly catching-up economies, and thus as one source for the middle-income trap phenomenon.
\end{abstract}

Keywords: Bilateral Trade; WTO; TRIPs; Intellectual Property Rights; Innovation; Middle Income Trap

JEL classification: F10; F13; O19; O31; O34

Acknowledgements: We thank Chong-sup Kim, Dukgeun Ahn, Jee-Hyeong Park, Kara Reynolds, U.S. ITC Commissioner Daniel Pearson, Patrick Messerlin, Emeric Henry, and Bart Verspagen for their helpful comments in the earlier versions of our paper. We are also grateful for discussions with Hochul Shin, Hea-Jung Hyun, Keun-Yeob Oh, Kazuhiko Yokota, Fukunari Kimura at the East Asian Economic Association 2012 conference and the $3^{\text {rd }}$ Asia Pacific Innovation Conference 2012. The second author acknowledges the financial support from the the Korean government through the National Research Foundation (NRF-2013S1A3A2053312). 


\section{Introduction}

Under the auspices of the World Trade Organization (WTO), free trade has been promoted as a vehicle for world economic development. The WTO also regulates and provides guidelines for intellectual property rights (hereinafter referred to as IPRs) through the TRIPS (Trade-Related Aspects of Intellectual Property Rights) Agreement. This Agreement has thus far represented the most extensive multilateral agreement towards the global harmonization of IPRs by setting out minimum standards for protection across member countries. These standards are also evolving through TRIPSPlus provisions incorporated in recent bilateral and regional trade agreements. Alongside these developments, we have also observed the increased globalization of technology in terms of increased international patent filings and export sales.

The theory and empirical research linking trade and IPRs has focused on the extent to which IPRs in the destination (or importing) country attract exports from the source country, controlling for other determinants of trade (see Maskus and Penubarti 1995; Smith 1999 and 2001; McCalman 2005; Awokuse and Yin 2009; and Ivus 2010). However, to determine the extent to which the expansion and enforcement of global IPRs has contributed to export growth requires that we break down the impacts by economic development, since developed and developing countries have critical differences in IPR systems (see Deere 2009) as well as varying levels of technological development. Exporting firms in the developed world have long been accustomed to a relatively advanced IPR system in their home market; in that regard, few of them needed to be equipped for the global institutional changes. On the other hand, many firms in the developing world have faced the challenge of meeting the conditions established by their nations' bounded commitments to TRIPS. Most exporting firms in 
the developing world are likely to incur higher costs in order to adapt to TRIPS obligations, even though TRIPS does not necessitate high standards but minimum requirements. In addition, stricter IPR laws and enforcement in developed countries might curb imports from developing countries, as the latters' exports would be excluded if they are found to be too imitative and infringing. In contrast, if a firm is innovative and commands a high level of technology, it would not face such difficulties in penetrating markets with higher levels of IPR protection. Thus, the effects of IPRs in the importing markets on the exports of source countries should depend upon the innovative capacity of the source country firms.

In this paper, we study the interaction effect of a destination country's IPR protection and a source country's level of technology on the level of bilateral trade between the source and destination countries. We measure the level of technology using a country's patents (which will be discussed more fully in the paper). This is the first paper, to our knowledge, which studies how the innovative capacity of the source country influences the relationship between IPRs and trade, and how foreign IPRs influence the marginal contribution of technology to export performance. Furthermore, previous empirical studies have focused on trade flows either by individual exporter countries or for a small number of bilateral trading partners. This paper is the first to use a large pooled panel dataset consisting of bilateral trade flows among more than 70 countries for the recent period (2000 to 2007). ${ }^{1}$ With this dataset, we conduct comparative analyses by income groups; for example, trade between North (developed countries) and South (developing countries), South and South, and North and North.

\footnotetext{
${ }^{1}$ For most developing countries and economies in transition, the year 2000 was their deadline to comply with TRIPS. Thus, 2000 is treated as the initial year for measuring the effects of IPRs.
} 
The paper finds some quite interesting results. First, when both the level of technology of the source country and the intellectual property strength of the destination country are taken into account jointly as an interaction term, the effect of an importer's IPR on a source country's export is highly dependent on the exporting country's LT. In other words, as an importing country's level of IPR increases, the net marginal effect of technology on exports decreases. This result is especially prominent in the case of exports from developing countries to the developed countries, but not so in the case of exports from the latter to the former. This asymmetry implies that the destination country's level of IPRs can act as a trade barrier, diminishing the exports from developing countries; in particular, the export growth of countries whose technological levels are currently emerging are likely to be impeded by the recent increased stringency of IP laws and policies.

However, exports from the developed countries are not thwarted by the IPR systems of their trading partners in the South. These contrasting results may support the view that the current IPRs system has a distributional bias in that a stronger global IPR regime favors the expansion of developed country exports relative to that of developing country exports. Our results show that, conditional on the levels of technology of different countries, the elasticity of exports with respect to IPRs is higher for developed countries than it is for developing, and that it can be even negative for some developing countries who are catching-up rapidly.

The organization of the paper is as follows. Section 2 provides a conceptual background for the paper and derives hypotheses. Section 3 describes the empirical method and the data employed. Section 4 discusses the empirical findings, along with several tests of robustness. Section 5 provides concluding remarks. 


\section{Conceptual Background and Hypothesis}

\section{1. TRIPs and International Trade}

TRIPS regulates minimum standards for domestic IPRs. Most developed economies have already surpassed the minimum criteria for TRIPS (Deere 2009 and Park 2008). However, for developing countries (or low technology exporters), higher global minimum IPR standards may be akin to a tax, in the sense that they increase $\mathrm{R} \& \mathrm{D}$ expenses for net technology borrowers who incur higher royalties and licensing fees (Glass and Saggi 2002, Siebeck et al 1990). To meet higher standards of IPRs, developing country exporters face higher production costs in order to access global information and enter into global markets (Helpman 1993; Lai and Qiu 2003). Moreover, as Auriol and Biancini (2010) and Odagiri et al. (2010) show, tighter global IPRs, particularly in developed country markets, can act as a barrier to the entry of developing country exports into advanced, developed country markets, particularly if developing country products are found to be infringing or too imitative under the IPR regime of the destination market, and thus cannot legally enter those markets. For developing country exporters that do enter the developed country markets, they would still face higher legal and administrative costs of procuring intellectual property rights, such as patents, as well as enforcing rights and contesting IP claims. Thus, two key burdens for developing economies exist under TRIPS. First, the domestic costs of establishing an IPR system in accordance with TRIPS have been rather exorbitant to the developing world (see Finger 2002 and Schneider 2005). ${ }^{2}$ Second, the global transactions costs of legal fees and

\footnotetext{
${ }^{2}$ For example, Schneider (2005) finds this implication in her empirical results. She also argues that strong domestic IPRs may hurt innovations in developing countries since their innovations
} 
litigation costs dampen the benefits of exporting if any dispute arises.

\section{[Insert Figure 1]}

In fact, the WTO's dispute settlement body has overseen numerous TRIPSrelated disputes, where so far 32 official cases have been heard since the inception of the WTO. ${ }^{3}$ Most cases (26 disputes) have been initiated by developed countries, primarily the United States and the European Union, and developing countries are involved in 16 disputes. $^{4}$ Moreover, firm-to-firm ${ }^{5}$ and national authority-to-firm disputes have been growing rapidly. For example, as Figure 1 shows, the U.S. International Trade Commission (U.S. ITC) has overseen a quadrupling of IPR-related disputes against foreign imports during the past two decades. ${ }^{6}$ Indeed, more American firms have complained against IPR violations than against unfair dumping, as the falling trend in traditional trade remedies such as anti-dumping (AD) and countervailing duties

are imitation or adaptive in nature.

${ }^{3}$ http://www.wto.org/english/tratop_e/trips_e/trips_e.htm, last accessed March, 2013.

${ }^{4}$ Unlike the cases against developed countries, all cases (10 cases) targeted against developing countries were settled out of the court or ruled against the developing countries. Firms in the developing countries tend to prefer out-of-court settlements or summary judgments due to concerns about litigation and legal costs.

${ }^{5}$ Within the border of the United States, firm-to-firm IPR-related disputes have drastically increased by over $100 \%$ in the past two decades, and patent-related cases have increased by about $150 \%$ from 1,224 cases in 1988 to 2,909 cases in 2008 (The U.S Courts, 2010).

6 The United States International Trade Commission (ITC) regulates IPR infringement by law with remedial actions called 'Section 337 investigation,' which directs U.S. Customs to block infringing imports from entering the United States market. The ITC can institute cease-anddesist proceedings against imports and named importers and other persons engaged in unfair acts that violate Section 337. Along with the United States, other developed countries such as the European Union (EU), Canada, and Japan also have strong IPR enforcement systems within their borders to block those infringing IPR imports. In the case of the EU, the European Commission enforces a powerful IPR protection system against imports that potentially violate IPRs through their Taxation and Customs Union office; IPR rights-holders can request that such imports be detained and under investigation. The actions can be requested on a national or on an EU basis. The number of requests for such actions has increased from nearly 1,000 applications in 2000 to over 18,000 in 2010 (European Commission, 2010). 
(CVD) appear to indicate. ${ }^{7}$ These developments indicate that the burden of global legal costs is quite real for exporters, especially those from developing countries.

\section{2. Level of Technology and Exports}

In addition to the world trade regime including TRIPs, the technology level of exporters (LT) can also influence the growth of trade. We assess a country's level of technology by examining its patents; for example, patents granted abroad or in the U.S. These patents capture a country's production of new technologies and hence serve as a useful indicator of the technological capabilities of firms in the country. These capabilities affect the possibilities of firms to capture global market share, given market conditions (including the level of IPRs). For developed economies, their level of technology has been a driving force behind their exports (Vernon 1996, Krugman 1979, Dollar 1986). Exporting firms in the developed world that engage in innovations exhibit greater export performance (Romer 1990; Grossman and Helpman 1991; Young 1991; Smith et al 2002; Becker and Egger 2007). Furthermore, awards of IPRs, such as patents for innovations, help signal product quality and thus stimulate market demand.

\section{[Insert Table 1]}

However, as shown in Table 1, the levels of technology (using patent data) vary between developed and developing countries, which raises questions about the derivation of economic benefits from TRIPS, such as the ability to gain export markets. In other words, is the global system of IPRs designed in favor of the exports of

\footnotetext{
${ }^{7}$ Note that the spikes in dumping investigations in 1992 and 2002 (and the slight rise in 2007-8) in Figure 1 may be due to recessions. Dumping complaints tend to be highly cyclical, increasing dramatically during recessions.
} 
countries with high levels of technology, LT? Table 1 shows the degree of differences in levels of technology using a country's patents granted abroad (i.e., to measure its acquisition of world patent rights) and a country's U.S. patents granted (i.e., to measure its unique inventions), as well as gaps in IPR protection between two income groups: developed and developing countries. Both in a relative (mean-wise) and absolute sense, the IPR gaps are smaller than the LT gaps between the two groups. ${ }^{8}$ The IPR gaps have become gradually narrowed since 2000 . In fact, the statistical differences in mean IPR values between the two groups have largely disappeared since 2005, the deadline year for implementing the TRIPS agreement by committed developing countries.

In fact, developing economies' products tend to be imitative in nature or invented (or re-invented) around existing products. Consequently, most of the exports of developing economies have not been products or processes protected by their own patent rights; they may be protected by a lower form of IPRs, such as utility models (namely petty patents), but not by regular patents (Kim et al. 2012). The implication here is that until a developing country approaches the technology levels of developed countries, strong IPRs in the exporting markets may serve as an obstacle to its exports.

\section{3. Interaction of IPR protection and the Level of Technology in Exports}

The theoretical literature thus far has identified two opposing effects of stronger IPRs in a destination country on the exports of a source country: a market-expansion effect and a market-power effect (Maskus and Penubarti, 1995). On the one hand, the

\footnotetext{
${ }^{8}$ The gap between the two groups in absolute mean value is huge. For example, in the developing country group, the mean LTs (as measured by foreign patent counts) for the years 2000-2001 and 2006-2007 are 96.41 and 226.31 respectively. The corresponding values in the developed group are 12279.73 and 17338.11 respectively. How we measure the strength of IPRs will be discussed in section 3 .
} 
exporters perceive an expansion in their market due to a reduction in imitation by local firms. The demand curve for their exports shifts out in the destination market. On the other hand, stronger IPRs in the destination country increase the exporters' market power, reducing the elasticity of the demand they face and thus the volume of exports. Hence, empirical analysis is typically pursued to see which effect dominates. ${ }^{9}$

However, one channel not analyzed thus far in the literature is the feedback effect of foreign IPRs and the exporter's level of technology on the exportability - or more specifically, on the profitability of exports - of the source country. The existing literature implicitly assumes that a source country has a sufficiently high level of technology that strong (or weak) foreign IPRs mainly affect the incentives of exporters to increase (or decrease) the volume of their exports (i.e., to weigh the market expansion and market power effects of stronger IPRs abroad). For countries where exporters do not have high levels of technology or innovative capacity, TRIPS-like standards in importing countries could dampen exports from these countries. ${ }^{10}$

For example, South Korea is currently a strong exporter, but its entry into the U.S. market has been marred by patent disputes between U.S. and Korean firms since the 1980s. A most noteworthy case was the ban on Samsung's computer chip exports imposed by the U.S. ITC for violating the patent rights of Texas Instruments. ${ }^{11}$ Thus, due to IP-induced barriers, developing countries could lose out on opportunities that exporting to developed markets provide, given that these latter markets account for the

\footnotetext{
9 See Taylor (1993), Maskus and Penubarti (1995), and Smith (1999, 2001).

10 The previous studies present mostly the perspective of developed countries (i.e., leading LT countries) on the adequacy of IPR protection for their exports in destination markets. For example, Maskus and Penubarti (1995) and Smith (1999) estimate the sensitivity of U.S. exports (or exports of OECD economies) to the level of IPRs across export markets using industry data, concluding that weak IPR levels are a barrier to U.S (or OECD) exports.

${ }^{11}$ For details, see Lee and Kim (2010).
} 
bulk of world markets and trading opportunities. The developing country exporters may find themselves confined to the technologically low-end of the market, which confers relatively smaller benefits. A more interesting aspect of this observation is that the possibly negative impact of this interaction between the levels of IPR protection and technology would be greater for those developing countries that are catching up rapidly, and thus command a certain level of technological capability and are active in exporting to the markets of developed countries, than for those developing countries with very low technological capabilities and thus weak export performances.

While the existing literature has not touched upon this interaction between IPRs and technological capabilities and its implications for exporting, this study explicitly considers this new channel of the impacts of IPRs on trade, namely the direct impact of IPRs and their indirect impact through their interaction with the exporter's level of technology.

\subsection{Hypotheses}

To illustrate our reasoning about the interaction effects, let us assume the following linear representation, allowing for some interaction between the source country's level of technology (LT) and the destination country's level of intellectual property rights (IPR). The value of exports (E) can then be considered to take the following functional form:

$$
\mathrm{E}(\mathrm{IPR}, \mathrm{LT}, .)=\alpha \mathrm{IPR}+\beta \mathrm{LT}+\gamma \mathrm{IPR} \times \mathrm{LT}+\ldots
$$

for which we can test whether $\gamma=0$. It is likely that $\beta>0$; namely, that exporting is a positive function of the level of technology. However, a priori, $\alpha$ and $\gamma$ are ambiguous, 
since the effect of IPRs on exports depend upon a balancing of the market power effects and market expansion effects of IPRs. Moreover, the cross effects of IPRs and the level of technology could in principle be either negative or positive. But the key advantage of having this interaction term is that the marginal impact of IPRs on exports is no longer simply $\alpha$ but the sum of two terms, namely $\alpha+\gamma \mathrm{LT}$, which represents the direct impacts $(\alpha)$ and the interaction impacts $(\gamma \mathrm{LT})$.

There are several possible cases to consider depending upon the signs of $\alpha$ and $\gamma$. However, the actual regressions, as will be shown later, all indicate $\gamma$ to be negative or sometimes insignificant. Thus, let us focus our discussion on this interesting and dominant case of $\gamma<0$. In this case, it is noteworthy that for some high ranges of the level of technology, the net marginal impact of IPRs on exports can be negative, such that $\frac{\partial \mathrm{E}}{\partial \mathrm{IPR}}=\alpha+\gamma \mathrm{LT}<0$, even if the direct impact of IPR is positive $(\alpha>0)$.

This possibility implies that the impact of IPRs might vary according to how much a country exports IP-sensitive products, which depend on the country's level of technology (i.e. patents). For a developing country with a low level of technology, its export items have not reached that status, as it exports less sophisticated products. In contrast, a small number of countries called "emerged or newly emerging economies," such as Korea, Taiwan, Malaysia, China, India, Russia, Brazil, Mexico, and several ASEAN countries, can produce technology-intensive products; their technology levels (LTs) are still low in comparison to developed countries but are relatively highest 
among developing countries. ${ }^{12}$ For them, strong IPR enforcement in the destination countries may act as a barrier against their exports into the markets of rich countries.

We can also gain a similar perspective by focusing on the impacts of changes in the level of technology of the exporters. Raising technological capabilities is one of the most important means by which exporters can expand their exports in foreign markets, and this is particularly pressing for the exporters in the South. However, the net impact of an additional increase in the level of technology of exporters might be small when there is a substantial negative interaction effect with the level of IPR protection in the destination countries. In other words, the marginal effect of the level of technology on exports can be expressed as $\frac{\partial \mathrm{E}}{\partial \mathrm{LT}}=\beta+\gamma \mathrm{IPR}$, which could be negative, even with a positive direct impact $(\beta)$, if $\gamma$ is negative and IPR takes on a sufficiently high value. This case is a clear-cut example of the entry barrier effect of IPRs which could frustrate the effort of the middle income countries to try to enter developed country markets by raising the technological standard of their products through innovation. This implies that one source of the so-called 'middle income trap' (Yusuf and Nabeshima 2009; World Bank 2010; Lee 2013) is weak exporting by the middle income countries into the markets of developed countries due to the latter's high IPR standards.

The concept of the middle-income trap refers to a situation in which middleincome countries face a slowdown of growth as they get caught between low-wage manufacturing and high-wage innovation because their wage rates are too high to

12 On average, $\$ 7.57$ billion of technology-intensive products (by the World Bank's classification) are exported from the developing countries, while \$ 30.13 billion of them are exported from the developed during $2000 \sim 2007$ (see more details in the Appendix). However, the amount of technology-intensive exports from the developing countries might be overestimated due to the presence of multinational corporations (MNCs) whose subsidiaries engage in exporting. 
compete with low-wage exporters and their level of technological capability is too low to allow them to compete with the advanced countries. One important way out of the trap is obviously to enhance their level of technologies (Lee 2013). However, the negative interaction between LT and IPRs implies that such efforts are impeded by the IPR protection of their destination countries.

From the above discussions, we now draw some research questions regarding the effects of IPRs and the level of technology on export behavior across countries. In particular, we suggest the following hypotheses for empirical testing:

(1) The possibly negative interaction effects between the level of technology and IPR protection would be more significant for exports from the South to the North than for exports from the North to the South.

(2) The impacts of the IPRs of destination countries on exports from abroad should vary depending upon the level of technology of the source countries. Specifically, the IPR effects on exports may be negative for those developing economies (the South) whose own level of technology is relatively high (i.e., $\frac{\partial E}{\partial I P R}=\alpha+\gamma \mathrm{LT}<$ 0 ), as strong IPRs may impede the entry of exports from countries that are catching up technologically.

(3) The direct impact $(\beta)$ of the level of technology on exports should be positive, but this positive impact may be offset by the negative interaction between the level of technology (LT) and the IPR protection of importing countries. This negative interaction effect should be more significant in the case of South-to-North exports. 


\section{Empirical Framework}

\section{1 Methodology}

Since we have many bilateral trading relations among countries, we employ standard gravity type models to explain the bilateral trade flows, in which the aggregate supply of the exporting country and the aggregate demand of the importing country are related to variables measuring transportation and transaction costs, along with other bilateral specific factors. ${ }^{13}$

The popular, extensive use of the gravity model suggests that it would be an appropriate empirical framework here to estimate the effects of patents, as a proxy for the level of technology (LT), and their interactions with IPRs. ${ }^{14}$ Let us first start with a canonical version of the gravity estimation equation:

$$
\ln E_{i j t}=\lambda_{i}+\lambda_{j}+\lambda_{i j}+\phi \ln G D P_{i t}+\phi \ln G D P_{j t}+\delta_{t}+\varepsilon_{i j t}
$$

where $E_{i j t}$ denotes real bilateral exports from country $i$ to country $j$ at time $t$ and $\ln$ the natural logarithm operator. $\mathrm{GDP}_{i t}$ and $\mathrm{GDP}_{j t}$ denote the real gross domestic products of each country. $\lambda_{i}, \lambda_{j}$ and $\delta_{t}$ are fixed exporter, importer, and time effects, respectively. $\lambda_{i}$ captures any exporter specific time-invariant effects such as the initial economic development of a country (e.g., initial conditions pertaining to political, cultural, traderelated infrastructure, or other institutional characteristics) and unobserved factor

${ }^{13}$ See Anderson and van Wincoop 2003; Anderson 2009; Baltagi et al 2003; and Fidrmuc 2009 for discussions of gravity models.

${ }^{14}$ Many IPRs and patent-related studies at the country-level have used also used gravity-type models (see Maskus and Penubarti 1995, Maskus 1998, Ginarte and Park 1997, Fink and Braga 1999, Glass and Saggi 2000 and 2001, Smith 2001, MacCalman 2005, Schneider 2005, and Awokuse and Yin 2010). 
endowment variables. ${ }^{15} \lambda_{j}$ accounts for any of these characteristics of the importing country. Time specific effects, $\delta_{t}$, control for common business cycle shocks (e.g. global supply and demand shocks, information technology booms or busts, natural resource price and demand increases in major emerging countries, such as China, Brazil and India). $\lambda_{i j}$ are the bilateral-pair fixed effects which control for all time-invariant factors, such as transportation costs (distance, remoteness) and other non-observable time-invariant factors between the two countries. ${ }^{16}$ The country-pair effects need not be symmetric but differ depending on the direction of trade $\left(\lambda_{i j} \neq \lambda_{j i}\right)$; for example, country $i$ may be a former colony of country $j$, but not vice versa.

Next, we augment the standard gravity model with the level of intellectual property rights and the level of technology variables:

$$
\begin{aligned}
\ln E_{i j t}=\lambda_{i}+\lambda_{j}+ & \lambda_{i j}+\phi \ln G D P_{i t}+\phi \ln G D P_{j t} \\
& +\alpha \ln I P R_{j t}+\beta \ln L T_{i t}+\gamma\left(\ln I P R_{j t} \times \ln L T_{i t}\right)+\delta_{t}+\varepsilon_{i j t}
\end{aligned}
$$

\footnotetext{
15 These factors are likely to be highly correlated with the gravity model variables (GDP, distance, language). Estimations which do not include them will have an endogeneity bias due to omitted variables, as long as the omitted variables are correlated with the bilateral trade or other explanatory variables.

${ }^{16}$ Our panel data method provides some general corrections introduced by country specific effects. Since our panel has relatively short time spans (4 periods), using these fixed effects with GLS (Generalized Least Squares) should be adequate to address serially correlated idiosyncratic errors (Baltagi and Wu 1999); however, omitted unobserved factors that have been bilaterally established can lead to bias (Baltagi et al 2003, Carrere 2006). For example, more often than not, bilateral or regional FTAs that include bilateral investment and IPR-related agreements require member countries to meet higher IPR standards than those set by TRIPS. Especially, technology-rich countries ratchet up IP protection through these agreements with extra provisions (the so-called TRIPS plus provisions) that go beyond the minimum requirements of TRIPS. Existence of these provisions may produce a bilateral bias for member countries to apply more stringent standards, which say limit the use of existing TRIPS flexibilities or public interest safeguards. Thus, in order to address this concern, bilateral-pair fixed effects are controlled for.
} 
where LT denotes the measure of the technology level referred to earlier. Our key variables of interest in equation (3) are the exporter's level of technology, the importer's intellectual property protection, and their interaction.

We expect the signs of the coefficients for $\operatorname{lnIPR}, \operatorname{lnLT}$, and $\operatorname{lnIPR} \times \ln L T$ to be in accordance with our discussion in section 2. First, the expected coefficient of intellectual property protection is ambiguous, as it depends on whether the market expansion or market power effect of the destination country's IPRs dominates. Second, the expected coefficient for the level of technology is positive since product quality and productivity should stimulate export growth and be especially important for developing country exporters to break into advanced country markets. Lastly, the interaction term will determine the interplay between the importer's IPR and exporter's level of technology, and will thereby be the basis for testing our hypotheses. To the extent that the importer's IPR impedes the exports of low technology products, we expect the coefficient of the interaction term to be negative for developing countries (and ambiguous for developed countries). That is, a large negative value of $\gamma$ in equation (3)

could result in IPRs having a net negative effect on exports: $\frac{\partial \mathrm{E}}{\partial \mathrm{IPR}}=\alpha+\gamma \mathrm{LT}<0$, depending on the level of technology (namely if LT $>-\alpha / \gamma$ ).

\subsection{Data Description}

Our trade data are from the United Nations Commodity Trade Statistics Database (UNCOMTRADE). The export values have been converted to constant 2000 U.S. dollars. The U.S. import price index from the U.S. Bureau of Labor Statistics is used as a proxy for the change in export prices in the world. 
As mentioned earlier, we measure LT using patents. We use two main versions ${ }^{17}$ : the first measures the level of technology in terms of diffusion; that is, the exporter's patents granted abroad (i.e., summed across all countries). The reasoning is that innovations that are high in technology content would be valuable to patent worldwide. This variable measures, therefore, a country's level of technology in terms of the global breadth of its innovations. However, the sum of all patents granted abroad is not a unique count of innovations; that is, the same innovation may be patented in multiple countries. Thus, as an alternative measure of the level of technology, we examine patents granted in the U.S. This would be a count of unique innovations. The reason for considering U.S. patents granted, rather than domestic (home-country) patents, is that more highly valuable innovations are patented abroad, particularly in a large market like the United States. Another advantage of using U.S. patents granted is that we incorporate a common patent granting standard. The disadvantage of examining patents granted in just one country is that we do not capture the marketability of technologies worldwide, particularly since exporters will likely seek patent protection in those markets where they expect to sell their products; thus, patents granted worldwide help to capture the trade-related technology levels of a country. Hence, by using our two measures of LT, we can both exploit their strengths and offset their weaknesses. Patent data are from the World Intellectual Property Office (WIPO) and the U.S. Patent and Trademark Office (USPTO). In either case, LT is calculated as the moving average of the current year and previous year, so as to smooth out cyclical movements.

Our measure of IPR is from the Global Competitiveness Report published by

\footnotetext{
17 European Patent Office and Trilateral patents are also a potential measure for LT at the country level. We discuss these alternative measures in our section on robustness checks.
} 
the World Economic Forum (WEF). This index is based on a survey of business executives in each reporting country. The survey asks for a rating between 1 and 7 , where higher numbers reflect a stronger perception of IPR strength and enforcement. There are some limitations with directly capturing the statutory characteristics of country's IPRs regime due to any experiential or perception errors on the part of survey participants. Despite this limitation, this index has an extensive coverage of countries and is important to the extent that it is the perceptions of IPR regimes that influence exporters' behavior. ${ }^{18}$

Some sample statistics of IPRs and LT are provided in Table 2, broken down by percentile values and development level. Generally, developed countries have a larger number of patents abroad and stronger domestic IPR regimes, while some of the emerging economies (e.g. China, India, Ukraine) have higher levels of technology relative to their stage of economic development (see more details in the Appendix).

\section{[Insert Table 2]}

The nominal GDPs are from the International Monetary Fund's World Economic Outlook database (2010) and are converted into real GDPs (in U.S. dollars) using GDP deflators. The data on bilateral trade costs were compiled using the gravity dataset of CEPII (Centre d'Etudes Prospectives et d'Informations Internationales-

\footnotetext{
${ }^{18}$ However, we also use the Ginarte and Park (1997) index of patent rights (based on statutory and case laws and regulations) to check for robustness. The initial years of GP-IPR index (2000) are used and treated as time invariant data in our regression since its time series are limited for our period of analysis 2000-2007 (i.e., the GP-IPR index has only two of those years: 2000 and 2005). The use of the initial year allows us to complement the WEF IPR index while avoiding multi-collinearity between the two IPR measures.
} 
Institute for Research on the International Economy). Bilateral distance is calculated using latitudes and longitudes of economic centers to calculate the great circle distances. The common language, border, and former colonial link are dummy variables, indicating " 1 " if two countries commonly share a geographical and cultural adjacency, and " 0 " otherwise. The bilateral trade dataset used for the regression analysis consists of 33 developed countries and 42 developing countries. Table 3 provides some descriptive statistics for the variables used in our regressions, for the full sample and for samples broken down by income group.

\section{[Insert Table 3]}

\section{Empirical Results}

\subsection{Individual and Interaction effects between LT and IPR}

Table 4 presents three ways of estimating our model using data for all countries. First, pooled OLS (Ordinary Least Squares) is presented in columns (1) (3) as a basic model. Second, GLS (Generalized Least Squares) with country effects using exporter/importer dummies and year dummies is presented in columns (4) (6). Third, panel fixed effect (FE) estimation, applied with two specific effects (bilateral-pair effects and year dummies), is presented in columns (7) and (8).

We first present our results using total world patents granted as our measure of a country's level of technology (see columns (1) (8) of Table 4) and then use patents granted in the U.S. as our measure of LT (see columns (9) (13), which show the GLS and FE estimates). Throughout, the coefficient estimates of GDP of both the exporter and importer and other control variables for bilateral-pair relations are statistically 
significant and positive, whereas the coefficient estimate of distance is statistically significant and negative. This is generally consistent with previous studies.

\section{[Insert Table 4]}

In the pooled sample of developed and developing countries, the effect of an importer's IPR on exports turns out to be positive and statistically significant at the $1 \%$ level (see Table 4, first row). This result indicates that exporters are motivated to export more to countries with a stronger IPR system, notwithstanding the level of an exporter's own level of economic development. These results are also confirmed in the previous literature (Maskus and Penubarti 1995; Fink and Braga 1999; Smith 2001; Rafiquzzaman 2002; Park and Lippoldt 2003; Awokuse and Yin 2009; Ivus 2010).

In addition, the effect of the exporter's technology level (LT) on its exports is positive and statistically significant at the $1 \%$ level across most of the specifications the exception being the two cases of positive but statistical insignificance in columns (4) and (7). In general, these initial results show that an increase in the level of technology (measured by the quantity of patents) is positively associated with an expansion in exports, which agrees with several previous empirical studies (e.g., Greenhalgh et al 1994; Montobbio and Rampa 2005; Cassiman et al 2010). Our findings are also qualitatively similar if we use patents granted in the U.S. as our measure of the level of technology (LT), as shown in columns (9) (13) of Table 4. Thus, whether we characterize a country's technology level in terms of its innovations or global diffusion, its technological activity is an importer driver of its exporting. These two findings are robust even if we control for the initial level of patent laws and regulations in the 
exporter and importer countries (see the EX-GPIPR-2000 and IM-GPIPR variables in Table 4, columns (3) and (6)).

Now, it is important to note that the coefficients on the interaction term $(\operatorname{lnIPR} \times \operatorname{lnLT})$ are statistically significant and negative in all the models except the one in column (13), regardless of whether the models include country-effects or bilateralpair effects. ${ }^{19}$ To better understand and interpret this result, we now proceed to the sets of regressions by different income groups. Our bilateral panel consisting of exporters as source countries and importers as destination markets allows us to conduct a comparative analysis by breaking up both the source and destination countries by income group (refer to the notes on 'Direction of Trade Flows' in Table 5).

Table 5 reports the results of separating the sample between developed (the North) and developing (the South) countries, using specifications with interaction terms. We use the World Bank definition of high-income countries to categorize the developed countries (see the Appendix for details). In the upper part, Columns (1) (4) show estimates for the exports of the North to the World, and columns (5) (8) show estimates for the exports of the South to the World. The models in the lower part of the table, or columns 9 to 16, show the various 2 by 2 combinations of the South and North, either as source or destination countries, such as exports from the North to North, North to South, South to North, and South to South.

\section{[Insert Table 5]}

\footnotetext{
19 We have also controlled for importer-year and exporter-year fixed effects, instead of having merely importer and exporter fixed effects. The rationale is that there may be time varying 'multilateral resistance terms' reflecting transportation costs and other border effects which prevent price arbitrage (see Anderson and van Wincoop (2003)). The qualitative results are quite similar if we use these particular fixed effects and are available upon request.
} 
First, we note that in both the cases of North to World and South to World, the interaction term has significantly negative coefficients. Next, when we turn to the 2 by 2 cases, we notice importantly that the same coefficients are still negative but not significant in the cases of North to South and South to South. In contrast, the interesting cases are the North exporting to the North and the South exporting to the North, where the interaction term's coefficients are negative and significant. This pattern confirms the first hypothesis proposed in the preceding section, namely that the possibly negative interaction effects between the level of technology and IPR protection would be more serious for the exports of the South to the North, than for the exports of the North to the South.

Since we are using log-log specifications, the interaction effect has an elasticity interpretation between real exports and the level of IPR; that is, the partial effect of IPR on $\mathrm{E}$ (holding other variables constant) is

$$
\% \Delta \mathrm{E}_{i j} \approx\left[\alpha+\gamma \ln \left(\mathrm{LT}_{i}\right)\right] \% \Delta \mathrm{IPR}_{\mathrm{j}}
$$

Now, if the coefficient of the interaction term, $\gamma$, is negative, this means that the positive effect of IPR protection alone $(\alpha)$ is offset by the negative interaction effect. This equation is plotted in Figures 2A for the case of exports from the South to the North. In this figure, we plot the estimated elasticity of exports with respect to IPRs, conditional on the level of technology; specifically for two values: a high level of LT and a low level of LT of the exporting countries, where the high value is one standard deviation of 
LT above its mean and the low value is one standard deviation of LT below its mean. ${ }^{20}$ The Figure shows that the impact of a higher level of IPR protection in the North on exports from countries in the South depends on the exporters' level of technology. For the Southern exporter with a low level of LT, a stronger IPR still helps promote the growth of its exports because the negative interaction effect is quantitatively too small to fully offset the positive effects of IPRs on exports. In contrast, for Southern exporters with a higher LT, the negative interaction effects are large enough to more than fully offset the positive and direct impact of IPR, and thus the net impacts are almost zero, making the slope of the elasticity curve very flat.

\section{[Figures 2A and 2B here]}

The estimated elasticities of exports with respect to IPR, evaluated at the mean levels of technology, suggest a distributional bias; namely, that global IPR reforms primarily raise the share of Northern exports in the world. For example, based on estimates in columns 1 and 5, the elasticity of world exports with respect to IPR is 0.898 for developed countries, using the mean value $\ln \mathrm{LT}=1.75$ (based on Table 1). This elasticity is lower, namely 0.68 , for developing countries, using the mean value $\ln \mathrm{LT}=$

\footnotetext{
${ }^{20}$ When there is an interaction effect, the appropriate evaluation of the effect should be tested with various interesting values of the concerned variables, such as the mean value, or the lower and upper quartiles in the sample. However, in order to show the interaction effect in a more precise but concise way, we compute the slope of $\ln (\mathrm{E})$ on $\ln (\mathrm{IPR})$ while holding the value of $\ln (\mathrm{LT})$ constant at either a high value of LT (one standard deviation (SD) above the mean) or a low value (one standard deviation (SD) below the mean) (Wooldridge 2009). The virtue of using this statistical technique of analyzing the interaction effect according to the standard deviation changes in the level of LT (or IPR), as centered on a certain percentile value (the mean in our case), is that we can avoid the errors that occur from arbitrarily classifying countries based on income level.
} 
1.22. Hence, a given percentage strengthening of IPRs increases Northern exports relatively more than Southern exports.

Let us next turn to the other side of coin and examine the impact of an exporters' level of technology on exports. The negative interaction between the level of technology and IPR protection implies that the positive export-promoting effects of LT would be substantially diminished. Actually, in the case of exports from the South to the North, the elasticity of exports with respect to the level of technology is negative for high IPR destinations, as shown in Figure 2B. Thus, the net effects of LT turn out to be negative for the case where the South exports to developed countries with high levels of IPR protection. In contrast, for Southern exports to developed countries with lower levels of IPR protection, the net effect seems to be negligible, given a very flat slope for the elasticity curve.

Analyzing sample percentiles from the perspective of exporters, we can graph the optimal or appropriate levels of IPR at which the growth of technological innovations promotes exports. These appropriate levels differ sharply between developed and developing economies. ${ }^{21}$ For example, in developed countries, export growth continues to respond positively to an increase in the importer's IPR until approximately the $80^{\text {th }}$ percentile of the importer's IPR level is reached. In contrast, the exports of developing countries are suppressed by foreign IPRs from even low levels of the importer's IPR strength; that is, at around the $10^{\text {th }}$ percentile.

Overall, these graphs and estimation results confirm our twin (second and third) hypotheses that the effect of IPR (or LT) on exports varies under different levels of LT

\footnotetext{
${ }^{21}$ In other words, with a percentile analysis of the interaction effects, we can empirically identify the optimal levels of IPR for the case of the North or the South as exporters to the World as the destination. See Kim et al. (2012) for a similar argument.
} 
(or IPR). Jointly, these hypotheses imply that IPR protection in the North may act as a barrier to the entry of Southern exports, especially of those exports whose level of technology LT is relatively high. In other words, the stringent protection of IPRs by the more advanced destination countries enables their domestic producers to exclude the products of foreign exporters whose levels of technology are catching-up. In reality, many cases exist that support this empirical finding. For example, incumbent firms in the North often resort to legal suit or disputes over IPRs in order to edge out competitors whose technological capabilities are growing and are a threat in their markets. As pointed out earlier, when Korea was still a developing country in the 1980s, Samsung Electronics had emerged as a rapidly growing competitor in the computer chips market. The U.S incumbent company, Texas Instruments, pursued patent infringement cases against Samsung that involved 10 of their patents on dynamic random access memory (DRAM). After the U.S. ITC had initiated extensive litigation and imposed a restriction on Samsung's exports, Samsung in the end agreed to renew a patent licensing agreement worth more than US\$ 1 billion as part of a settlement with Texas Instruments. ${ }^{22}$

These results are in sharp contrast to the case of the North's exports to the South, for which case the coefficients of the interaction term between the North's LT and the South's IPR are not significant. This implies that IPR protection in the South does not interfere with Northern exporting. This asymmetry implies that developed country exporters are possibly the major beneficiaries of a strong IPR system, as created by TRIPS in the current world trading system, and that their own IPR regimes work as a mechanism to diminish the ability of developing countries to access their markets by

\footnotetext{
${ }^{22}$ For details, see Lee and Kim (2010) in Odagiri et al. (2012).
} 
enhancing the level of technology of developing economies. In other words, the stronger Northern IPR system appears to obstruct those Southern exports that have higher LTs.

\section{2. Robustness Checks}

In this section, we discuss the robustness of our results to alternative measures of IPRs and the level of technology (LT) and examine issues related to lagged effects, patent quality, and emerging economies. These are reported in Tables $6-8$. In Table 6 we replicate our sets of baseline regressions from Table 4 and 5 using EPO (European Patent Office) patents as a measure of LT. The regression outcomes are more or less consistent with those produced by the previous LT measures, leading us to draw the same conclusions. ${ }^{23}$ Again, the coefficients of the interaction term between LT and IPRs are negative and significant in the case of exports from the South to the North, whereas they are not significant in the case of exports from the North to the South.

We also test for robustness using an alternative measure of IPRs that reflects the perception of IPR enforcement. This recent measure of IPR protection is based on annual surveys by the Economist Intelligence Unit (EIU). ${ }^{24}$ The results are shown in Table 7A. Compared to the World Economic Forum's IPR index, we can observe more variation among countries in the EIU's IPR index, although the latter covers fewer countries. We have also checked the sensitivity of our results to missing and zero values

\footnotetext{
${ }^{23}$ The results are also robust to using patent priority filings, instead of U.S. patents granted, as a way of obtaining a unique count of innovations by country of inventor.

${ }^{24}$ In the survey, respondents rate their countries' protection of intellectual property on a scale from 1 to 5, with 1 being "very poor" and 5 being "very good." The EIU mobilizes its network of regional experts and pools the opinions of specific country experts to survey both the perceived protection of IPRs and the implementation of existing laws.
} 
of LT and IPR in the sample. ${ }^{25}$ Thus far, we had excluded these observations and so we checked whether the results change significantly if we include them. ${ }^{26}$ These checks are reported in Table 7B.

So far, for the 4 combinations (N-N, N-S, S-N, and S-S), we have run a total of 8 regressions, as presented in Tables 5, 6, and 7A-B. In all of these 8 regressions, the coefficients of the interaction term in the South to North export regressions have always been negative and significant, and those in the North to South export regressions have not been significant in all the regressions, except in one. In general, the South-to-South trades also seem to be negatively affected by the higher IPR protection of their partner countries, as the coefficients are always negative but significant in 6 out of 8 cases. This is important, given the relatively higher level of IPR protection in the South compared to its generally lower level of technologies. The results of the North-North trade vary, with the coefficient of the interaction term being negative and significant in half the cases, and positive but insignificant in a couple of them.

Finally, in Table 8, we explore four further issues: 1) the impact of IPR on the emerging economies of the South with high levels of technological capabilities (LT); 2) the sensitivity of the results to the lagging of LT; 3) considerations of the quality of patents in LT; and 4) the use of non-patent measures of LT, such as the measure of technological sophistication of exports used in Hausmann et al. (2007). To address these issues, we focus on the exports of the South to the North where these issues seem most

\footnotetext{
${ }^{25}$ As our dependent variable has only a few zero observations at the bilateral level (6.93\%), Tobit or Poisson Pseudo Maximum likelihood (PPML) methods do not alter our results.

${ }^{26}$ Where IPR data are missing for certain countries (usually they are those with gross national income per capita of less than \$975), we assign a value to their IPR that equals the minimum sample score for IPR. We then also include observations with patent grants equal to zero.
} 
relevant and of concern. ${ }^{27}$

In columns $1-4$, we form subgroups of the Southern (developing) countries. In the first sub-sample, we separate the top twenty developing countries in terms of the level of technology, where LT is all patenting abroad, from the rest of the developing country sample. In a second sub-sample, we separate the BRICs (Brazil, Russia, India, and China) from the rest. The results are consistent with our previous findings in Table 5. The coefficient of the interaction term, $\gamma$, is significantly negative. The IPRs of the North are shown to impede the exports of rapidly emerging economies, such as the BRICs and other high LT developing economies, in a greater degree than in average developing countries, as the absolute value of the negative coefficient for the former group is bigger than for the latter group..

Next, in columns 5 to 8 of Table 8 , we test the sensitivity of lagging the LT measures. It may be the case that past patenting more accurately captures the level of a country's technology than its current patenting since it takes time for patented inventions to result in exportable products. We thus take Table 5, columns 13 and 14, as our baseline specifications and introduce the once and twice lagged levels of technology, $\mathrm{LT}_{\mathrm{t}-1}$ and $\mathrm{LT}_{\mathrm{t}-2}$, respectively. The results show that even allowing for lagged effects, our qualitative findings remain unchanged.

Next, in columns 9 to 12 of Table 8 , we control for the quality of patents in the measure of the technology level of developing countries. Mere counts may overstate the LT of these economies. We adjust for patent quality in two ways. The first is to select those developing country patents that are Trilateral patents, namely those patents that are filed in the three major markets: the U.S., Japan, and the European Patent

27 The results for the other blocs and directions of trade are available upon request. 
Office (EPO) area. Trilateral patents can be viewed as relatively higher quality since inventors (or exporters) self-select. Since international patenting is costly, firms select their most valuable technologies to patent in the trilateral markets. Hence, the subset of LT that is trilateral can be a measure of high quality patents. ${ }^{28}$ The second way to adjust for patent quality is to weight a country's patents by the average citations received in its U.S. patent grants. ${ }^{29}$ The rationale is that patents that are more heavily cited have greater technological impacts. While these quality adjustments decrease the measured LT for developing countries, we retain our findings that Northern IPRs crowd out the exports of Southern economies with high levels of technology.

Lastly, we measure the technological content of exports more directly, without resorting to a country's patenting to infer the technology level. Following Hausmann et al. (2007), we construct a variable EXPY which measures the productivity level of a country's export basket. We first derive a measure of the sophistication of a product, PRODY, as a weighted average of the per-capita GDP of the countries that export it, where the weights are the relative comparative advantage (RCA) of each country in exporting the good. We then compute EXPY as a weighted average of the PRODY in each country, where the weights are export shares of products. Columns $13-16$ show the results of using EXPY instead of LT in our regressions. Again, the qualitative results are similar; the coefficient signs of our key variables are the same, but the

\footnotetext{
${ }^{28}$ Data for trilateral patents come from the European Patent Office (EPO)'s PRI database.

${ }^{29}$ We obtained citation data and the weighted citations from the NBER's database Patent Data Project (https://sites.google.com/site/patentdataproject/Home/downloads). The citations indicator is adjusted for the truncation bias in which older patents necessarily receive more citations. We use the "quality-adjusted" counts of U.S. patents granted after some adjustments since there are many missing observations (intrinsically the patent citation is biased toward the North) in our sample. To minimize the observation loss, we take the time average of citations (or weighted-citations) in our sample period and multiply that to the number of U.S. patents granted.
} 
coefficient estimates are magnified.

\section{Conclusion}

This paper investigated several questions regarding the effects of an exporter's technology level, an importer's IPR, and the interactions among them on bilateral exports. The first question concerned the individual or direct effect of the levels of either IPR protection or technology on export behavior. Consistent with previous work (e.g. Cassiman et al 2010; Becker and Egger 2007), we found that on average, technological innovations, as measured by the number of patents granted abroad or U.S patents, have a positive impact on exporting, and that on average, the level of IPRs protection by importing countries has a positive impact on exporting, controlling for other factors. These findings on the individual (direct) effects of the two variables suggest that IPR protection in a destination country helps induce exports from both developed and developing countries, and that innovative capacity is a strong determinant of the exporting of developing countries.

Now, a hidden story behind the impact of IPRs on export behavior is revealed when we consider the second question, which concerns the interaction effect between the exporter's technology level and the importer's IPRs. When both of these factors are included as an interaction term, the effect of IPRs (or LT) on export growth involves both direct and indirect interaction effects, and thus is highly dependent on the level of an exporting country's level of technology (or importing country's level of IPRs). This paper finds that in the case of developing countries, the coefficient of the interaction term is negative when they export to the North; in contrast, in the case of developed countries exporting to the South, this coefficient is not significant. Thus, in the case of exports from the South to the North, the negative coefficient of the interaction effect 
fully offsets the direct and positive effects of IPRs (or LT) on exports. Especially for those Southern countries whose level of technology is catching up rapidly to that of the North, these negative impacts tend to be bigger, which results in an overall negative impact of an exporter's LT on exports, or almost a zero impact of a Northern importer's IPRs on exports from the South. We have conducted a battery of robustness tests and found this result to arise consistently. The above results suggest that IRP protection creates a 'distributional bias' in favor of exporters from developed countries relative to those from developing, because strong IPRs act as an obstacle to trade, discouraging exporting from the South that are in the process of catching-up in terms of their level of technology, and in this sense as one source of the middle-income trap.

Lastly, we suggest some ideas for future research. First, we have not distinguished between bilateral trade among countries with free trade agreements (FTA) and that among countries without such agreements. The possible FTA effect, however, was controlled by bilateral-pair fixed effects. The FTA among trading partners should be an explicit, additional factor to consider in future studies since FTAs involve both IPR and trade-related influences. Second, while the effects of IPR protection and technologies may vary by sectors, this study has not allowed such sectoral heterogeneity in the analysis. This requires heavier data work but should be pursued in future work. Third, the interesting interaction between IPRs and technology on exports can be the basis for serious theoretical modeling. 


\section{References}

Anderson, James E. and van Wincoop, Eric, 2003. "Gravity with Gravitas: A Solution to the Border Puzzle." American Economic Review 93 (1): 170-192.

Andresen, Martin A. 2009 "The Border Puzzle is Solved," Applied Economics Letters 16 (16): $1617-1620$.

Auriol, Emmanuelle and Biancini, Sara, 2010. "Intellectual Property Rights Adoption in Developing Countries," TSE Working Papers 09-094, Toulouse School of Economics (TSE).

Awokuse, Titus O. and Yin, Hong, 2010. "Does Stronger Intellectual Property Rights Protection Induce More Bilateral Trade? Evidence from China's Imports," World Development 38 (8): 1094-1104.

Baltagi, Badi H. and Wu, Ping X., 1999. "Unequally Spaced Panel Data Regressions with AR (1) Disturbances," Econometric Theory 15 (06): 814-823.

Baltagi, Badi H. and Egger, Peter and Pfaffermayr, Michael, 2003. "A Generalized Design for Bilateral Trade Flow Models," Economics Letters 80 (3): 391-397.

Becker, Sascha O. and Egger, Peter, 2009. "Endogenous Product versus Process Innovation and a Firm's Propensity to Export," Empirical Economics.

Carrere, Celine, 2006. "Revisiting the Effects of Regional Trade Agreements on Trade Flows With Proper Specification of The Gravity Model," European Economic Review 50 (2): 223-247.

Cassiman, Bruno and Golovko, Elena and Martínez-Ros, Ester, 2010. "Innovation, Exports and Productivity," International Journal of Industrial Organization 28 (4): 372-376.

Correa, Carlos M., 2007, Trade-Related Aspects of Intellectual Property Rights: A Commentary on the TRIPS Agreement, Oxford University Press.

Deere, Carolyn, 2009. The Implementation Game: the TRIPS Agreement and the Global Politics of Intellectual Property Reform in Developing Countries, Oxford University Press, USA.

European Commission. 2010. Report on EU customs enforcement of intellectual property rights Results at the EU border - 2010, Taxation and customs union.

Fidrmuc, Jarko, 2009. "Gravity Models in Integrated Panels," Empirical Economics 37 (2): 435-446.

Eaton, Jonathan and Kortum, Samuel, 1996. "Trade in Ideas Patenting and Productivity in the OECD," Journal of International Economics 40 (3-4): 251-278.

Fink, Carsten and Braga, Carlos A. Primo, 1999. "How Stronger Protection of Intellectual Property Rights Affects International Trade Flows," Policy Research Working Paper Series 2051, The World Bank. 
Glass, Amy Jocelyn and Saggi, Kamal, 2002. "Intellectual Property Rights and Foreign Direct Investment," Journal of International Economics 56 (2): 387-410.

Ginarte, J.C., Park, W.G., 1997. "Determinants of Patent Rights: A Cross-National Study." Research Policy 26: 283-301.

Greenhalgh C., Taylor P., Wilson R., 1994. "Innovation and Export Volumes and Prices: A Disaggregated Study," Oxford Economic Papers 46 (1): 102-134.

Grossman, Gene and Elhanan Helpman 1991. "Endogenous Product Cycles." Economic Journal 101: 1214-1229.

Helpman, E., 1993. "Innovation, Imitation, and Intellectual Property Rights." Econometrica 61 (6): 1247-1280.

Hausmann, R., Hwang, J., and Rodrik, D. (2007) "What you export matters." Journal of Economic Growth 12:1-25.

Ivus, O., 2010. "Do Stronger Patent Rights Raise High-Tech Exports to the Developing World?" Journal of International Economics 81 (1): 38-47.

Jaffe, A. B. 2000. "The U.S. Patent System in Transition: Policy Innovation and The Innovation Process." Research Policy 29: 531-557.

Kim, Yee Kyoung, Keun Lee, Walter G. Park, and Kineung Choo, 2012, “Appropriate Intellectual Property Protection and Economic Growth in Countries at Different Levels of Development," Research Policy 41(2): 358-375.

Lai, Edwin and Larry Qiu, 2003. "The North's Intellectual Property Rights Standard for the South?” Journal of International Economics 59: 183-209.

Lee, K. 2013, Schumpeterian Analysis of Economic Catch-up: Knowledge, Pathcreation, and the Middle Income Trap. Cambridge: Cambridge Univ. Press.

Lee. K. and Y. K. Kim, 2010. "IPR and Technological Catch-Up in Korea." in Intellectual Property Rights, Catch-Up and Development: an International Comparative Study, Odagiri, H., Goto, A., Sunami, A., and Nelson, R. (eds.), 133-167, Oxford University Press.

Maskus, Keith E., 1998. "The International Regulation of Intellectual Property," Review of World Economics (Weltwirtschaftliches Archiv) 134 (2): 186-208.

Maskus, K.E., Penubarti, M., 1995. "How Trade Related Are Intellectual Property Rights?" Journal of International Economics 39: 227-248.

McCalman, Phillip 2005. "Who Enjoys 'TRIPs' Abroad? An Empirical Analysis of Intellectual Property Rights in the Uruguay Round," Canadian Journal of Economics 38 (2): 574-603.

Montobbio F, Rampa F., 2005. "The Impact of Technology and Structural Change on Export Performance in Developing Countries," World Development 33 (4):527547.

Odagiri, H., Goto, A., Sunami, A., and Nelson, R., 2010. Intellectual Property Rights and Catch-Up: an International Comparative Study, Oxford University Press.

Park, W. G., 2008. "International Patent Protection: 1960-2005," Research Policy 37: 761-766. 
Park, W. G. and Lippoldt, D., 2005. "International Licensing and Strengthening of Intellectual Property Rights in Developing Countries during the 1990s," OECD Economic Studies, 40: 7 - 42.

Rafiquzzaman, Mohammed, 2002. "The Impact of Patent Rights on International Trade: Evidence from Canada," Canadian Journal of Economics 35 (2): 307-330.

Siebeck, Wolfgang E., 1990, "Strengthening Protection of Intellectual Property in Developing Countries: A Survey of the Literature," Robert E. Evenson, William Lesser, and Carlos A. Primo Braga (eds.) (Washington, D.C.: World Bank).

Schneider, P. H., 2005. "International Trade, Economic Growth and Intellectual Property Rights: A Panel Data Study of Developed and Developing Countries," Journal of Development Economics 78 (2): 529-547.

Smith, P. J., 1999. “Are Weak Patent Rights A Barrier To U.S. Exports?” Journal of International Economics 48: 151-177.

Smith, P. J., 2001. "How do patent rights affect U.S exports, affiliates, sales, and licenses? Journal of International Economics 55: 411-439.

Taylor, M.S., 1993. "TRIPS, Trade, and Technology Transfer," Canadian Journal of Economics 26: 625-638.

UNCTAD, 1996. "Economic and Legal Implications for the Developing Countries of Implementing the TRIPS Agreement," UNCTAD.

U.S. Courts, 2010. "Annual Report of the Director: Judicial Business of the United States Courts," Administration Office of the U.S. Courts.

Vernon, Raymond, 1966. "International Investment and International Trade in the Product Cycle," Quarterly Journal of Economics 80: 190-207.

Wooldridge, Jeffrey M. 2009. Introductory Econometrics: A Modern Approach, 4 ed. South-Western.

World Bank, 2010, 'Exploring the Middle-Income-Trap', World Bank East Asia Pacific Economic Update: Robust Recovery, Rising Risks, vol. 2, Washington, DC: The World Bank.

World Development Indicators (WDI), 2010, CD-ROM, Published by World Bank.

World Economic Forum, 2007. Global Competitiveness Report 2006-2007, New York: Palgrave Macmillan.

Yusuf, S. and Nabeshima, K., 2009. 'Can Malaysia Escape the Middle Income Trap? A Strategy for Penang', Policy Research Working Paper 4971, Washington, DC: The World Bank. 
Table 1. Gaps of Exporter's LT and Importer's IPR level between the Two Groups

\begin{tabular}{|c|c|c|c|c|c|c|}
\hline \multicolumn{3}{|c|}{ Variable Comparison By Group } & $2000-2001$ & $2002-2003$ & 2004-2005 & 2006-2007 \\
\hline \multirow{5}{*}{$\begin{array}{l}\text { Exporter's Average } \\
\text { LT Level } \\
\text { Measuring by } \ln L T_{\mathrm{ALL}}\end{array}$} & \multirow{4}{*}{$\begin{array}{l}\text { Developing } \\
\text { (the South) } \\
\text { Developed } \\
\text { (the North) }\end{array}$} & Obs. & 4,908 & 5,818 & 6,028 & 6,263 \\
\hline & & Mean & 2.114 & 3.348 & 3.413 & 3.702 \\
\hline & & Obs. & 5,723 & 5,810 & 5817 & 5,908 \\
\hline & & Mean & 6.861 & 7.727 & 7.726 & 7.928 \\
\hline & \multicolumn{2}{|c|}{ Difference (p-value) } & $\begin{array}{l}-4.747 * * * \\
(0.000)\end{array}$ & $\begin{array}{l}-4.379 * * * \\
(0.000)\end{array}$ & $\begin{array}{l}-4.313 * * * \\
(0.000)\end{array}$ & $\begin{array}{l}-4.226 * * * \\
(0.000)\end{array}$ \\
\hline \multirow{5}{*}{$\begin{array}{l}\text { Exporter's Average } \\
\text { LT Level } \\
\text { Measuring by } \operatorname{lnLT}_{\text {US }}\end{array}$} & \multirow{2}{*}{$\begin{array}{l}\text { Developing } \\
\text { (the South) }\end{array}$} & Obs. & 4,908 & 5,818 & 6,028 & 6,263 \\
\hline & & Mean & 2.303 & 2.298 & 2.212 & 2.308 \\
\hline & \multirow{2}{*}{$\begin{array}{l}\text { Developed } \\
\text { (the North) }\end{array}$} & Obs. & 5,723 & 5,810 & 5817 & 5,908 \\
\hline & & Mean & 5.939 & 6.025 & 5.882 & 5.988 \\
\hline & \multicolumn{2}{|c|}{ Difference (p-value) } & $\begin{array}{l}-3.636^{* * * *} \\
(0.000)\end{array}$ & $\begin{array}{l}-3.727 * * * \\
(0.000)\end{array}$ & $\begin{array}{l}-3.670 * * * \\
(0.000)\end{array}$ & $\begin{array}{l}-3.680 * * * \\
(0.000)\end{array}$ \\
\hline \multirow{5}{*}{$\begin{array}{l}\text { Importer's Average } \\
\text { lnIPR level }\end{array}$} & \multirow{2}{*}{$\begin{array}{l}\text { Developing } \\
\text { (the South) }\end{array}$} & Obs. & 2,502 & 2,871 & 2,896 & 2,957 \\
\hline & & Mean & 4.159 & 4.146 & 4.111 & 4.142 \\
\hline & \multirow{2}{*}{$\begin{array}{l}\text { Developed } \\
\text { (the North) }\end{array}$} & Obs. & 2,462 & 2,466 & 2,408 & 2,476 \\
\hline & & Mean & 4.142 & 4.131 & 4.097 & 4.128 \\
\hline & \multicolumn{2}{|c|}{ Difference (p-value) } & $\begin{array}{l}0.017 * * \\
(0.049)\end{array}$ & $\begin{array}{c}0.015^{*} \\
(0.087)\end{array}$ & $\begin{array}{c}0.014 * \\
(0.097)\end{array}$ & $\begin{array}{c}0.013 \\
(0.101)\end{array}$ \\
\hline
\end{tabular}

Note: The level of technology (LT) and IPRs are our main variables for regression analysis. LT level is measured by $\mathrm{LT}_{\mathrm{ALL}}$ (Total patents granted abroad) or $\mathrm{LT}_{\mathrm{US}}$ (Patents granted in the U.S.). The World Economic Forum (WEF) IPR index is used to measure the level of IPRs.

This test is conducted with data on the bilateral-trade pairs used later on in our regression analysis (see the list of sample countries and their mean values of LT and IPR in the Appendix): Difference = mean (developing) - mean (developed). We report the p-values of the Two-group mean-comparison test, $t$-test statistics (assuming unequal variance). $*, * *$ and $* * *$ indicate that the equality in mean values between developing and developed countries can be rejected at the $90 \%, 95 \%$ and $99 \%$ confidence levels respectively.

Table 2. LT and IPR percentile Values for Developed and Developing Countries

\begin{tabular}{cccccccc}
\hline \multirow{2}{*}{ Percentile } & \multicolumn{4}{c}{ North } & \multicolumn{2}{c}{ South } & \multicolumn{3}{c}{$\operatorname{lnIPR}_{j}$} \\
& $\operatorname{lnLT}_{\text {ALL }}$ & $\operatorname{lnLT}_{\text {US }}$ & $\operatorname{lnLT}_{\text {ALL }}$ & $\operatorname{lnLT}_{\text {US }}$ & $\underline{\text { All }}$ & North & South \\
\hline \hline 1th & 0.00 & 1.10 & 0.00 & 0.00 & 3.51 & 3.81 & 3.43 \\
25th & 5.72 & 3.89 & 1.10 & 0.70 & 3.90 & 4.27 & 3.77 \\
50th & 8.26 & 6.25 & 3.18 & 2.01 & 4.12 & 4.45 & 3.94 \\
75th & 9.40 & 7.41 & 5.15 & 3.57 & 4.42 & 4.54 & 4.08 \\
99th & 11.92 & 11.37 & 7.54 & 6.24 & 4.61 & 4.61 & 4.38 \\
\hline S. D & 2.85 & 2.54 & 2.28 & 1.74 & 0.31 & 0.19 & 0.22 \\
\hline
\end{tabular}

Note: S.D (Standard Deviation) presented here is to calculate and plot two-way interaction effects at fixed values of moderating variables (i.e. value of sample variables is demeaned). 
Table 3. Summary of Basic Statistics for Variables

\begin{tabular}{|c|c|c|c|c|c|c|c|c|c|c|c|c|c|c|c|}
\hline \multirow{2}{*}{ Variable } & \multicolumn{5}{|c|}{$\underline{\text { All Countries }}$} & \multicolumn{5}{|c|}{$\underline{\text { Developed Countries }}$} & \multicolumn{5}{|c|}{$\underline{\text { Developing Countries }}$} \\
\hline & Obs. & Mean & S.D. & Min & Max & Obs. & Mean & S.D. & Min & Max & Obs. & Mean & S.D. & Min & $\operatorname{Max}$ \\
\hline lnReal Export ${ }_{i j}$ (bilateral Export) & 46,275 & 15.67 & 3.62 & 0.00 & 26.34 & 3,258 & 16.40 & 3.51 & 0.00 & 26.34 & 3,017 & 14.93 & 3.58 & 0.55 & 25.94 \\
\hline $\mathrm{LT}_{i t}$ (Measured by Exporter's Patents granted Abroad: ALL) & 46,275 & 8,201 & 25,061 & 0.00 & 177,874 & 23,258 & 16,120 & 33,517 & 0.00 & 177,874 & 23,017 & 199 & 408 & 0.00 & 2,675 \\
\hline $\operatorname{lnLT}_{i t}$ (Measured by Exporter's US Patents granted) & 46,275 & 4.13 & 2.84 & 0.00 & 11.38 & 23,258 & 5.96 & 2.49 & 0.00 & 11.38 & 23,017 & 2.28 & 1.78 & 0.00 & 6.58 \\
\hline LT $_{i t}$ (Measured by Exporter's US Patents granted) & 46,275 & 2,560 & 11,500 & 0.00 & 87,432 & 23,258 & 5,047 & 15,833 & 0.00 & 87,432 & 23,017 & 47 & 104 & 0.00 & 717 \\
\hline IPR $_{j t}$ (WEF IPR Index of Importers) & 21,110 & 65.22 & 19.38 & 29.69 & 100 & 9,884 & 64.71 & 19.23 & 29.69 & 100 & 11,226 & 65.66 & 19.49 & 29.69 & 100 \\
\hline $\operatorname{lnIPR}_{j t}($ EIU IPR Index of Importers) & 16,218 & 4.07 & 0.46 & 3.00 & 4.61 & 7,484 & 4.05 & 0.47 & 3.00 & 4.61 & 8,734 & 4.08 & 0.46 & 3.00 & 4.61 \\
\hline $\mathrm{IPR}_{j t}(\mathrm{EIU}$ IPR Index of Importers) & 16,218 & 3.21 & 1.29 & 1.00 & 5.00 & 7,484 & 3.17 & 1.29 & 1.00 & 5.00 & 8,734 & 3.25 & 1.29 & 1.00 & 5.00 \\
\hline $\ln (\mathrm{LT}) \times \ln (\mathrm{IPR})\left(\right.$ Interaction between $\left.\mathrm{LT}_{\mathrm{ALL}} \& \mathrm{IPR} \mathrm{WEF}\right)$ & 21,110 & 20.71 & 14.03 & 0.00 & 55.67 & 9,884 & 30.37 & 11.96 & 0.00 & 55.67 & 11,226 & 12.20 & 9.46 & 0.00 & 36.34 \\
\hline $\ln (\mathrm{LT}) \times \ln (\mathrm{IPR})($ Interaction between LTus \&IPRwEF $)$ & 21,110 & 15.79 & 11.78 & 0.00 & 52.40 & 9,884 & 23.92 & 10.65 & 0.00 & 52.40 & 11,226 & 8.64 & 7.21 & 0.00 & 30.28 \\
\hline $\ln (\mathrm{LT}) \times \ln (\mathrm{IPR})\left(\right.$ Interaction between $\left.\mathrm{LT}_{\mathrm{ALL}} \& \mathrm{IPR}_{\mathrm{EIU}}\right)$ & 16,218 & 20.06 & 13.97 & 0.00 & 55.67 & 7,484 & 29.67 & 12.21 & 0.00 & 55.67 & 8,734 & 11.83 & 9.37 & 0.00 & 36.34 \\
\hline InEX-GPIPR-2000 (Ginarte-Park IPR index in 2000) & 43,405 & 1.29 & 0.25 & 0.24 & 1.58 & 21,455 & 1.44 & 0.12 & 1.01 & 1.58 & 21,950 & 1.14 & 0.25 & 0.24 & 1.49 \\
\hline lnIM-GPIPR-2000 (Ginarte-Park IPR index in 2000) & 29,629 & 1.10 & 0.35 & 0.06 & 1.58 & 14,302 & 1.08 & 0.35 & 0.06 & 1.58 & 15,327 & 1.11 & 0.34 & 0.06 & 1.58 \\
\hline IM-GPIPR-2000 (Ginarte-Park IPR index in 2000) & 29,629 & 3.16 & 0.98 & 1.06 & 4.88 & 14,302 & 3.11 & 0.98 & 1.06 & 4.88 & 15,327 & 3.21 & 0.98 & 1.06 & 4.88 \\
\hline $\operatorname{lnRGDP}_{i t}$ (Real GDP of Exporters) & 46,275 & 5.20 & 1.65 & 1.66 & 9.47 & 23,258 & 5.70 & 1.51 & 1.97 & 9.47 & 23,017 & 4.70 & 1.62 & 1.66 & 8.09 \\
\hline $\operatorname{lnRGDP}_{i t}$ (Real GDP of Importers) & 42,504 & 3.38 & 2.39 & -5.63 & 9.47 & 21,187 & 3.22 & 2.39 & -5.63 & 9.47 & 21,317 & 3.54 & 2.39 & -5.63 & 9.47 \\
\hline lnDistance $_{i j}$ (Distance) & 45,164 & 8.68 & 0.84 & 4.09 & 9.89 & 22,634 & 8.60 & 0.86 & 4.09 & 9.89 & 22,530 & 8.76 & 0.81 & 4.66 & 9.89 \\
\hline Continuity $_{i j}$ (Common Border) & 45,164 & 0.02 & 0.14 & 0.00 & 1.00 & 22,634 & 0.02 & 0.12 & 0.00 & 1.00 & 22,530 & 0.03 & 0.16 & 0.00 & 1.00 \\
\hline CoLang $i j$ (Common Language) & 45,164 & 0.13 & 0.34 & 0.00 & 1.00 & 22,634 & 0.14 & 0.34 & 0.00 & 1.00 & 22,530 & 0.13 & 0.34 & 0.00 & 1.00 \\
\hline CoLink $_{i j}$ (Former Colonial link) & 45,164 & 0.02 & 0.15 & 0.00 & 1.00 & 22,634 & 0.03 & 0.17 & 0.00 & 1.00 & 22,530 & 0.01 & 0.11 & 0.00 & 1.00 \\
\hline
\end{tabular}

Note: 'ln' stands for the natural logarithm. Key variables such as LT and IPR are indicated both in natural logarithm and units. There are 75 export countries and 195 import countries in the sample. Potentially, 58,200 bilateral pairs can be permutated $(75 \mathrm{x}(195-1) \mathrm{x} 4$ periods). The sample of variable is reduced to a great extent when some variables such as lnIPR and its interaction variables are included. Their pairs are only matched when there is no missing value in the both import and export side of the variables. 
Table 4. Impacts of LTs and IPRs on Export: all countries

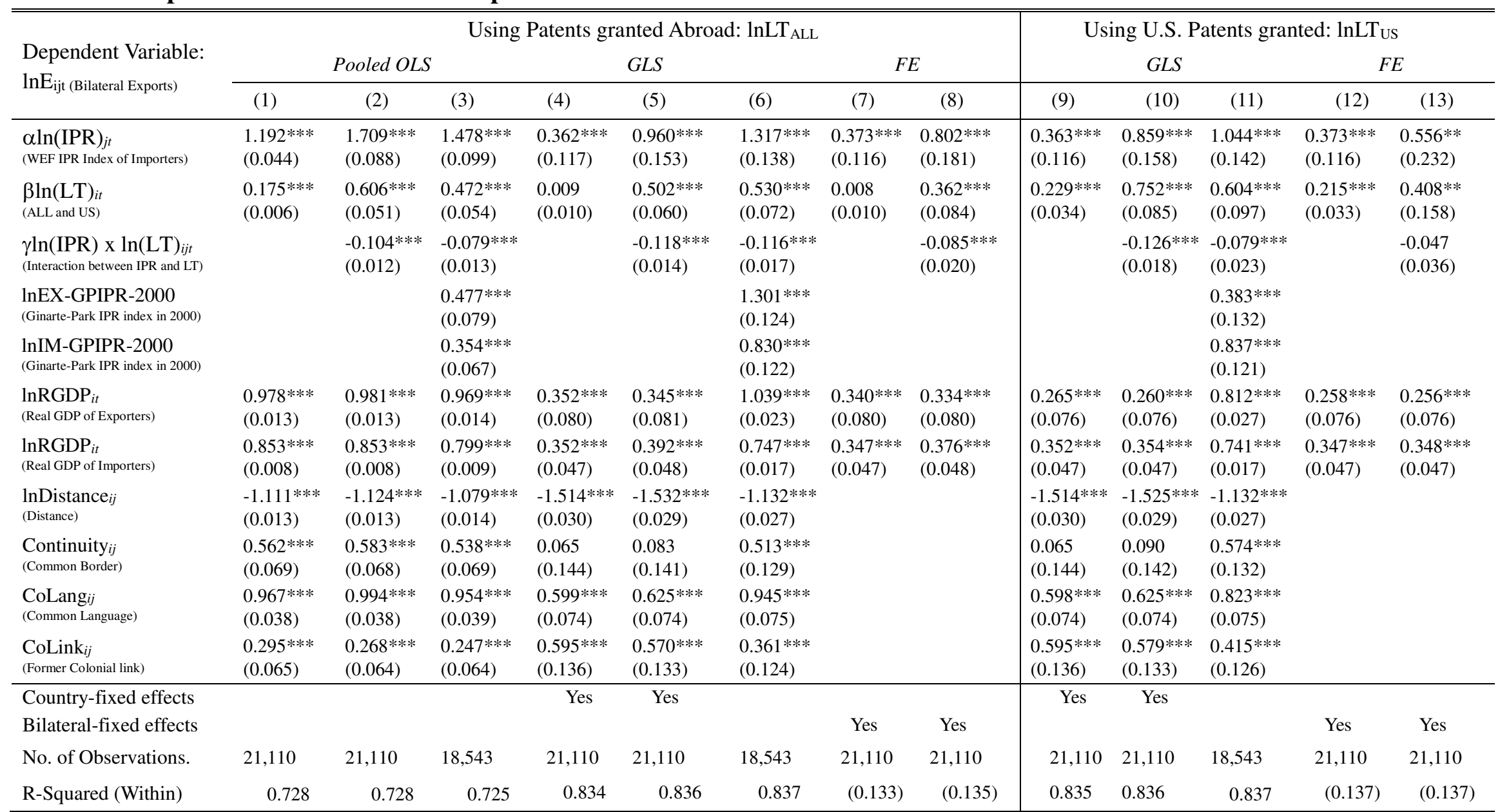

Notes: * significance at $10 \%$ level, ** significance at $5 \%$ level, and *** significance at $1 \%$ level, respectively. Robust standard errors are in parentheses.

The time dummies and constants are not reported even if they are included in all specifications. Coefficient estimates for fixed/time effects are not reported.

The level of technology is measured in two ways; column $(1) \sim(8)$ presents the results of regression using all patents granted abroad (lnLT $\mathrm{ALL})$ whereas column (9) $\sim(13)$ uses patents granted in the U.S. ( $\left(\operatorname{lnLT}_{\mathrm{US}}\right)$ as a measure of the level of technology. 
Table 5. Impacts of LTs and IPRs on Export by Income Group

\begin{tabular}{|c|c|c|c|c|c|c|c|c|}
\hline \multirow{4}{*}{$\begin{array}{l}\text { Dependent } \\
\text { Variable: } \\
\text { lnE }_{\text {ijt (Bilateral Exports) }}\end{array}$} & \multicolumn{4}{|c|}{ 1. North-to-World } & \multicolumn{4}{|c|}{ 2. South-to-World } \\
\hline & \multicolumn{2}{|c|}{$\operatorname{lnLT}_{\mathrm{ALL}}$} & \multicolumn{2}{|c|}{$\operatorname{lnLT}_{\mathrm{US}}$} & \multicolumn{2}{|c|}{$\operatorname{lnLT}_{\mathrm{ALL}}$} & \multicolumn{2}{|c|}{$\operatorname{lnLT}_{\mathrm{US}}$} \\
\hline & $G L S$ & $F E$ & GLS & $F E$ & $G L S$ & $F E$ & $G L S$ & $F E$ \\
\hline & (1) & (2) & (3) & (4) & (5) & (6) & (7) & (8) \\
\hline $\begin{array}{l}\alpha \ln (\mathrm{IPR})_{j t} \\
\text { (WEF IPR Index of Importers) }\end{array}$ & $\begin{array}{l}1.057 * * * \\
(0.214)\end{array}$ & $\begin{array}{l}0.376 * * * \\
(0.116)\end{array}$ & $\begin{array}{l}0.956 * * * \\
(0.231)\end{array}$ & $\begin{array}{l}0.381 * * * \\
(0.118)\end{array}$ & $\begin{array}{l}0.935 * * * \\
(0.223)\end{array}$ & $\begin{array}{l}0.363 * \\
(0.195)\end{array}$ & $\begin{array}{l}0.901 * * * \\
(0.233)\end{array}$ & $\begin{array}{l}0.377 * \\
(0.197)\end{array}$ \\
\hline $\begin{array}{l}\beta \ln (\mathrm{LT})_{i t} \\
\text { (ALL and US) }\end{array}$ & $\begin{array}{l}0.418 * * * \\
(0.093)\end{array}$ & $\begin{array}{l}0.042 * * * \\
(0.015)\end{array}$ & $\begin{array}{l}0.574 * * * \\
(0.146)\end{array}$ & $\begin{array}{l}0.173^{* * *} \\
(0.087)\end{array}$ & $\begin{array}{l}0.811^{* * *} \\
(0.105)\end{array}$ & $\begin{array}{l}-0.056^{* * * *} \\
(0.016)\end{array}$ & $\begin{array}{l}1.304 * * * \\
(0.172)\end{array}$ & $\begin{array}{l}0.178^{* * *} \\
(0.039)\end{array}$ \\
\hline $\begin{array}{l}\gamma \ln (\mathrm{IPR}) \times \ln (\mathrm{LT})_{i j t} \\
\text { (Interaction between IPR\& LT) }\end{array}$ & $\begin{array}{l}-0.091 * * * \\
(0.021)\end{array}$ & $\begin{array}{l}-0.069 * * * \\
(0.026)\end{array}$ & $\begin{array}{l}-0.097 * * * \\
(0.028)\end{array}$ & $\begin{array}{l}-0.049 \\
(0.054)\end{array}$ & $\begin{array}{l}-0.209 * * * \\
(0.025)\end{array}$ & $\begin{array}{l}-0.154 * * * \\
(0.031)\end{array}$ & $\begin{array}{l}-0.267 * * * \\
(0.039)\end{array}$ & $\begin{array}{l}-0.164 * * \\
(0.073)\end{array}$ \\
\hline $\begin{array}{l}\phi \operatorname{lnRGDP}{ }_{i t} \\
\text { (Real GDP of Exporters) }\end{array}$ & $\begin{array}{l}-0.558 * * * \\
(0.188)\end{array}$ & $\begin{array}{l}-0.547 * * * \\
(0.185)\end{array}$ & $\begin{array}{l}-0.456^{* * * *} \\
(0.177)\end{array}$ & $\begin{array}{l}-0.445^{* *} \\
(0.175)\end{array}$ & $\begin{array}{l}0.704 * * * \\
(0.093)\end{array}$ & $\begin{array}{l}0.697 * * * \\
(0.093)\end{array}$ & $\begin{array}{l}0.542 * * * \\
(0.088)\end{array}$ & $\begin{array}{l}0.542^{* * *} * \\
(0.088)\end{array}$ \\
\hline $\begin{array}{l}\phi \ln \mathrm{RGDP}_{i t} \\
\text { (Real GDP of Importers) }\end{array}$ & $\begin{array}{l}0.367 * * * \\
(0.045)\end{array}$ & $\begin{array}{l}0.366 * * * \\
(0.045)\end{array}$ & $\begin{array}{l}0.345^{* * * *} \\
(0.045)\end{array}$ & $\begin{array}{l}0.348 * * * \\
(0.045)\end{array}$ & $\begin{array}{l}0.444 * * * \\
(0.088)\end{array}$ & $\begin{array}{l}0.406 * * * \\
(0.088)\end{array}$ & $\begin{array}{l}0.365 * * * \\
(0.086)\end{array}$ & $\begin{array}{l}0.347 * * * \\
(0.086)\end{array}$ \\
\hline Country-fixed effects & Yes & & Yes & & Yes & & Yes & \\
\hline Bilateral-fixed effects & & Yes & & Yes & & Yes & & Yes \\
\hline No. of Observations. & 9,884 & 9,884 & 9,884 & 9,884 & 11,226 & 11,226 & 11,226 & 11,226 \\
\hline R-Squared (Within) & 0.879 & $(0.164)$ & 0.879 & $(0.162)$ & 0.797 & $(0.136)$ & 0.797 & $(0.136)$ \\
\hline \multirow{3}{*}{ Using $\operatorname{lnLT} T_{\mathrm{ALL}}$} & \multicolumn{2}{|c|}{ 3. North-to-North } & \multicolumn{2}{|c|}{ 4.North-to-South } & \multicolumn{2}{|c|}{ 5.South-to-North } & \multicolumn{2}{|c|}{ 6.South-to-South } \\
\hline & $G L S$ & $F E$ & GLS & $F E$ & $G L S$ & $F E$ & $G L S$ & $F E$ \\
\hline & (9) & (10) & (11) & (12) & (13) & (14) & (15) & (16) \\
\hline $\begin{array}{l}\alpha \ln (\mathrm{IPR})_{j t} \\
\text { (WEF IPR Index of Importers) }\end{array}$ & $\begin{array}{l}1.518^{* * * *} \\
(0.516)\end{array}$ & $\begin{array}{l}-0.021 \\
(0.200)\end{array}$ & $\begin{array}{l}0.498 \\
(0.354)\end{array}$ & $\begin{array}{l}0.832 * \\
(0.496)\end{array}$ & $\begin{array}{l}1.479 * * * \\
(0.390)\end{array}$ & $\begin{array}{l}0.586^{* *} \\
(0.295)\end{array}$ & $\begin{array}{l}0.440 \\
(0.325)\end{array}$ & $\begin{array}{l}0.543 \\
(0.397)\end{array}$ \\
\hline $\begin{array}{c}\beta \ln \left(\mathrm{LT}_{\mathrm{ALL}}\right)_{i t} \\
\text { (All Foreign Patents) }\end{array}$ & $\begin{array}{l}0.953 * * * \\
(0.326)\end{array}$ & $\begin{array}{l}0.050 * * \\
(0.019)\end{array}$ & $\begin{array}{l}0.131 \\
(0.196)\end{array}$ & $\begin{array}{l}0.345 \\
(0.277)\end{array}$ & $\begin{array}{l}1.958 * * * \\
(0.393)\end{array}$ & $\begin{array}{l}-0.072 * * * \\
(0.021)\end{array}$ & $\begin{array}{l}0.646^{* * *} \\
(0.278)\end{array}$ & $\begin{array}{l}0.686^{*} \\
(0.414)\end{array}$ \\
\hline$\underset{\text { (Interaction between IPR\& LT) }}{\gamma \ln (\mathrm{IPR}) \times \ln (\mathrm{LT})_{i j t}}$ & $\begin{array}{l}-0.206^{* * *} \\
(0.071)\end{array}$ & $\begin{array}{l}-0.237 * * * \\
(0.088)\end{array}$ & $\begin{array}{l}-0.000 \\
(0.045)\end{array}$ & $\begin{array}{l}-0.059 \\
(0.068)\end{array}$ & $\begin{array}{l}-0.410^{* * *} \\
(0.089)\end{array}$ & $\begin{array}{l}-0.262 * * * \\
(0.065)\end{array}$ & $\begin{array}{l}-0.106 \\
(0.068)\end{array}$ & $\begin{array}{l}-0.125 \\
(0.103)\end{array}$ \\
\hline $\begin{array}{l}\phi \operatorname{lnRGDP} i t \\
\text { (Real GDP of Exporters) }\end{array}$ & $\begin{array}{l}-0.569 * * \\
(0.237)\end{array}$ & $\begin{array}{l}-0.578^{* *} \\
(0.234)\end{array}$ & $\begin{array}{l}-0.435^{*} \\
(0.250)\end{array}$ & $\begin{array}{l}-0.394 \\
(0.246)\end{array}$ & $\begin{array}{l}0.576 * * * \\
(0.120)\end{array}$ & $\begin{array}{l}0.724 * * * \\
(0.126)\end{array}$ & $\begin{array}{l}0.513 * * * \\
(0.128)\end{array}$ & $\begin{array}{l}0.519 * * * \\
(0.128)\end{array}$ \\
\hline $\begin{array}{l}\phi \operatorname{lnRGDP}_{i t} \\
\text { (Real GDP of Importers) }\end{array}$ & $\begin{array}{l}0.310 \\
(0.198)\end{array}$ & $\begin{array}{l}0.334 * \\
(0.195)\end{array}$ & $\begin{array}{l}0.368 * * * \\
(0.048)\end{array}$ & $\begin{array}{l}0.371 * * * \\
(0.048)\end{array}$ & $\begin{array}{l}0.255 \\
(0.305)\end{array}$ & $\begin{array}{l}0.240 \\
(0.303)\end{array}$ & $\begin{array}{l}0.461 * * * \\
(0.097)\end{array}$ & $\begin{array}{l}0.455^{* * *} \\
(0.096)\end{array}$ \\
\hline Country-fixed effects & Yes & & Yes & & Yes & & Yes & \\
\hline Bilateral-fixed effects & & Yes & & Yes & & Yes & & Yes \\
\hline No. of Observations. & 4,190 & 4,190 & 5,694 & 5,694 & 5,071 & 5,071 & 6,155 & 6,155 \\
\hline R-Squared (Within) & 0.894 & $(0.266)$ & 0.851 & $(0.129)$ & 0.829 & $(0.153)$ & 0.773 & $(0.133)$ \\
\hline
\end{tabular}

Notes: *significance at $10 \%$ level, **significance at $5 \%$ level, and ***significance at $1 \%$ level, respectively. Robust standard errors are in parentheses. The time dummies, constants and the same gravity control variables in Table 4 are included even if they are not reported. Independent and control variables of Columns (2) (4), (6) (8) and (10) (14) are demeaned for graphical analysis. $\operatorname{lnLT}_{\mathrm{ALL}}$ presents the results where all patents granted abroad are used, whereas columns denoting $\ln L T_{\text {us }}$ use patents granted in the U.S. as a measure of the level of technology. Columns (9) (16) use only $\operatorname{lnLT}_{\mathrm{ALL}}$ since the other measure produces similar implications.

Directions of trade flows;

1. North-to-World, Column (1) - (4): Exporter is developed and Importer (destination) is all countries.

2. South-to-World, Column (5) - (8): Exporter is developing and Importer (destination) is all countries.

3. North-to-North, Column (9) - (10): Exporter is developed and Importer (destination) is developed.

4. North-to-South, Column (11) - (12): Exporter is developed and Importer (destination) is developing.

5. South-to-North, Column (13) - (14): Exporter is developing and Importer (destination) is developed.

6. South-to-South, Column (15) - (16): Exporter is developing and Importer (destination) is developing. 
Table 6. Impacts of LTs and IPRs on Export: Robustness check (using European Patents as a Measure of LT)

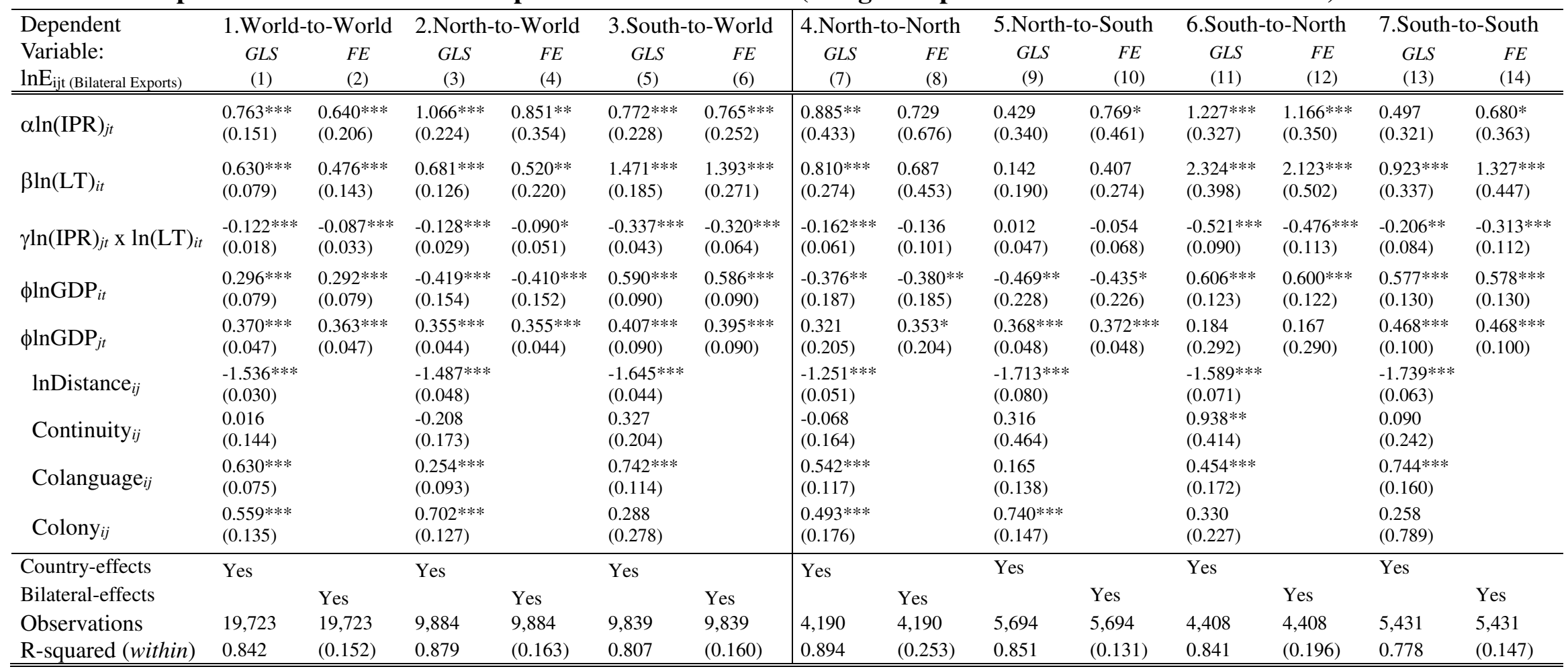

Notes: $*$ significance at $10 \%$ level, $* *$ significance at $5 \%$ level, and $* * *$ significance at $1 \%$ level, respectively. Robust standard errors are in parentheses.

The time dummies and constants are not reported even if they are included in all specifications. Coefficient estimates for fixed/time effects are not reported.

Directions of trade flows;

1. World-to-World, Column (1) and (2): Exporter is all countries and Importer (destination) is all countries

2. North-to-World, Column (3) and (4): Exporter is developed and Importer (destination) is all countries.

3. South-to-World, Column (5) and (6): Exporter is developing and Importer (destination) is all countries.

4. North-to-North, Column (7) and (8): Exporter is developed and Importer (destination) is developed.

5. North-to-South, Column (9) and (10): Exporter is developed and Importer (destination) is developing.

6. South-to-North, Column (11) and (12): Exporter is developing and Importer (destination) is developed.

7. South-to-South, Column (13) and (14): Exporter is developing and Importer (destination) is developing. 
Table 7. Impacts of LTs and IPRs on Export: Robustness check

\begin{tabular}{|c|c|c|c|c|c|c|c|c|c|c|c|c|c|c|}
\hline \multirow{2}{*}{$\begin{array}{l}\text { Dependent } \\
\text { Variable: } \\
\text { lnE } E_{\mathrm{ijt}} \text { (Bilateral Exports) }\end{array}$} & \multicolumn{2}{|c|}{ 1.World-to-World } & \multicolumn{2}{|c|}{ 2.North-to-World } & \multicolumn{2}{|c|}{ 3.South-to-World } & \multicolumn{2}{|c|}{ 4.North-to-North } & \multicolumn{2}{|c|}{ 5.North-to-South } & \multicolumn{2}{|c|}{ 6.South-to-North } & \multicolumn{2}{|c|}{ 7.South-to-South } \\
\hline & $\begin{array}{l}G L S \\
\text { (1) }\end{array}$ & $\begin{array}{l}F E \\
\text { (2) }\end{array}$ & $\begin{array}{l}G L S \\
\text { (3) }\end{array}$ & $\begin{array}{l}F E \\
(4)\end{array}$ & $\begin{array}{l}G L S \\
(5)\end{array}$ & $\begin{array}{l}F E \\
(6)\end{array}$ & $\begin{array}{l}G L S \\
\text { (7) }\end{array}$ & $\begin{array}{l}F E \\
(8)\end{array}$ & $\begin{array}{l}G L S \\
\text { (9) }\end{array}$ & $\begin{array}{l}F E \\
(10)\end{array}$ & $\begin{array}{l}G L S \\
(11)\end{array}$ & $\begin{array}{l}F E \\
(12)\end{array}$ & $\begin{array}{l}G L S \\
(13)\end{array}$ & $\begin{array}{l}F E \\
(14)\end{array}$ \\
\hline Country-effects & Yes & & Yes & & Yes & & Yes & & Yes & & Yes & & Yes & \\
\hline Bilateral-effects & & Yes & & Yes & & Yes & & Yes & & Yes & & Yes & & Yes \\
\hline$\alpha \ln (\mathrm{IPR})_{j t}$ & $\begin{array}{l}0.833 * * * * \\
(0.089)\end{array}$ & $\begin{array}{l}0.756 * * * \\
(0.101)\end{array}$ & $\begin{array}{l}0.920 * * * \\
(0.128)\end{array}$ & $\begin{array}{l}0.788^{* * * *} \\
(0.132)\end{array}$ & $\begin{array}{l}0.772 * * * \\
(0.123)\end{array}$ & $\begin{array}{l}0.707 * * * \\
(0.130)\end{array}$ & $\begin{array}{l}0.746 \\
(0.494)\end{array}$ & $\begin{array}{l}0.256 \\
(0.593)\end{array}$ & $\begin{array}{l}0.585^{* * * *} \\
(0.178)\end{array}$ & $\begin{array}{l}0.726^{* * * *} \\
(0.179)\end{array}$ & $\begin{array}{l}-0.043 \\
(0.349)\end{array}$ & $\begin{array}{l}-0.338 \\
(0.354)\end{array}$ & $\begin{array}{l}0.499 * * * \\
(0.163)\end{array}$ & $\begin{array}{l}0.581 * * * \\
(0.172)\end{array}$ \\
\hline$\beta \ln (\mathrm{LT})_{i t}$ & $\begin{array}{l}0.327 * * * \\
(0.041)\end{array}$ & $\begin{array}{l}0.243 * * * \\
(0.050)\end{array}$ & $\begin{array}{l}0.265 * * * \\
(0.056)\end{array}$ & $\begin{array}{l}0.189 * * * \\
(0.057)\end{array}$ & $\begin{array}{l}0.538 * * * \\
(0.079)\end{array}$ & $\begin{array}{l}0.367 * * * \\
(0.094)\end{array}$ & $\begin{array}{l}0.496 * * * \\
(0.190)\end{array}$ & $\begin{array}{l}0.201 \\
(0.252)\end{array}$ & $\begin{array}{l}0.098 \\
(0.073)\end{array}$ & $\begin{array}{l}0.168^{* *} \\
(0.072)\end{array}$ & $\begin{array}{l}0.827 * * * \\
(0.217)\end{array}$ & $\begin{array}{l}0.318 \\
(0.249)\end{array}$ & $\begin{array}{l}0.184^{*} \\
(0.109)\end{array}$ & $\begin{array}{l}0.253 * * \\
(0.125)\end{array}$ \\
\hline$\gamma \ln (\mathrm{IPR}) \times \ln (\mathrm{LT})_{i j t}$ & $\begin{array}{l}-0.081 \text { *** } \\
(0.010)\end{array}$ & $\begin{array}{l}-0.060^{* * * *} \\
(0.012)\end{array}$ & $\begin{array}{l}-0.059^{* * *} \\
(0.013)\end{array}$ & $\begin{array}{l}-0.041 \text { *** } \\
(0.014)\end{array}$ & $\begin{array}{l}-0.144 * * * \\
(0.018)\end{array}$ & $\begin{array}{l}-0.103^{* * * *} \\
(0.022)\end{array}$ & $\begin{array}{l}-0.107 * * \\
(0.042)\end{array}$ & $\begin{array}{l}-0.040 \\
(0.056)\end{array}$ & $\begin{array}{l}-0.019 \\
(0.020)\end{array}$ & $\begin{array}{l}-0.039^{*} \\
(0.020)\end{array}$ & $\begin{array}{l}-0.205 * * * \\
(0.048)\end{array}$ & $\begin{array}{l}-0.090^{*} \\
(0.056)\end{array}$ & $\begin{array}{l}-0.054^{*} \\
(0.028)\end{array}$ & $\begin{array}{l}-0.075 * * \\
(0.033)\end{array}$ \\
\hline$\phi \operatorname{lnRGDP} i t$ & $\begin{array}{l}0.319 * * * \\
(0.088)\end{array}$ & $\begin{array}{l}0.305 * * * \\
(0.088)\end{array}$ & $\begin{array}{l}-0.379 * * \\
(0.167)\end{array}$ & $\begin{array}{l}-0.352 * * \\
(0.165)\end{array}$ & $\begin{array}{l}0.569 * * * \\
(0.102)\end{array}$ & $\begin{array}{l}0.565^{* * * *} \\
(0.101)\end{array}$ & $\begin{array}{l}-0.381^{*} \\
(0.206)\end{array}$ & $\begin{array}{l}-0.390 * \\
(0.203)\end{array}$ & $\begin{array}{l}-.0 .371 \text { *** } \\
(0.256)\end{array}$ & $\begin{array}{l}-0.317 \\
(0.253)\end{array}$ & $\begin{array}{l}0.672 * * * \\
(0.138)\end{array}$ & $\begin{array}{l}0.669 * * * \\
(0.137)\end{array}$ & $\begin{array}{l}0.478 * * * \\
(0.149)\end{array}$ & $\begin{array}{l}0.467 * * * \\
(0.147)\end{array}$ \\
\hline$\phi \operatorname{lnRGDP} i t$ & $\begin{array}{l}0.211 * * * \\
(0.068)\end{array}$ & $\begin{array}{l}0.187 * * * \\
(0.068)\end{array}$ & $\begin{array}{l}0.131^{* *} \\
(0.062)\end{array}$ & $\begin{array}{l}0.115^{*} \\
(0.061)\end{array}$ & $\begin{array}{l}0.317 * * * \\
(0.120)\end{array}$ & $\begin{array}{l}0.271^{* *} \\
(0.119)\end{array}$ & $\begin{array}{l}-0.084 \\
(0.159)\end{array}$ & $\begin{array}{l}-0.082 \\
(0.159)\end{array}$ & $\begin{array}{l}0.291 * * * \\
(0.035)\end{array}$ & $\begin{array}{l}0.281 * * * \\
(0.073)\end{array}$ & $\begin{array}{l}0.085 \\
(0.291)\end{array}$ & $\begin{array}{l}0.078 \\
(0.287)\end{array}$ & $\begin{array}{l}0.504 * * * \\
(0.148)\end{array}$ & $\begin{array}{l}0.505 * * * \\
(0.145)\end{array}$ \\
\hline $\begin{array}{l}\text { No. of Observations. } \\
\text { R-Squared (Within) }\end{array}$ & $\begin{array}{l}16,218 \\
0.830\end{array}$ & $\begin{array}{l}16,218 \\
(0.169)\end{array}$ & $\begin{array}{l}7,484 \\
0.873\end{array}$ & $\begin{array}{l}7,484 \\
(0.246)\end{array}$ & $\begin{array}{l}8,734 \\
0.785\end{array}$ & $\begin{array}{l}8,734 \\
(0.152)\end{array}$ & $\begin{array}{l}3,575 \\
0.885\end{array}$ & $\begin{array}{l}3,575 \\
(0.243)\end{array}$ & $\begin{array}{l}3,909 \\
0.857\end{array}$ & $\begin{array}{l}3,909 \\
(0.254)\end{array}$ & $\begin{array}{l}4,396 \\
0.820\end{array}$ & $\begin{array}{l}4,396 \\
(0.155)\end{array}$ & $\begin{array}{l}4,338 \\
0.770\end{array}$ & $\begin{array}{l}4,338 \\
(0.158)\end{array}$ \\
\hline$\alpha \ln (\mathrm{IPR})_{j t}$ & $\begin{array}{l}0.488^{* * * *} \\
(0.115)\end{array}$ & $\begin{array}{l}0.496 * * * \\
(0.115)\end{array}$ & $\begin{array}{l}0.467 * * * \\
(0.120)\end{array}$ & $\begin{array}{l}0.443^{* * * *} \\
(0.120)\end{array}$ & $\begin{array}{l}0.499 * * * \\
(0.193)\end{array}$ & $\begin{array}{l}0.541^{* * * *} \\
(0.192)\end{array}$ & $\begin{array}{l}-0.006 \\
(0.197)\end{array}$ & $\begin{array}{l}-0.031 \\
(0.194)\end{array}$ & $\begin{array}{l}0.598 * * * \\
(0.147)\end{array}$ & $\begin{array}{l}0.578^{* * * *} \\
(0.147)\end{array}$ & $\begin{array}{l}0.716^{* *} \\
(0.292)\end{array}$ & $\begin{array}{l}0.722 * * \\
(0.290)\end{array}$ & $\begin{array}{l}0.415^{*} \\
(0.240)\end{array}$ & $\begin{array}{l}0.471 * * \\
(0.240)\end{array}$ \\
\hline$\beta \ln (\mathrm{LT})_{i t}$ & $\begin{array}{l}0.040 * * \\
(0.019)\end{array}$ & $\begin{array}{l}0.029 \\
(0.019)\end{array}$ & $\begin{array}{l}-0.042 \\
(0.043)\end{array}$ & $\begin{array}{l}-0.065 \\
(0.043)\end{array}$ & $\begin{array}{l}0.059 * * \\
(0.025)\end{array}$ & $\begin{array}{l}0.049^{* * *} \\
(0.025)\end{array}$ & $\begin{array}{l}-0.020 \\
(0.076)\end{array}$ & $\begin{array}{l}-0.049 \\
(0.075)\end{array}$ & $\begin{array}{l}-0.064 \\
(0.054)\end{array}$ & $\begin{array}{l}-0.076 \\
(0.054)\end{array}$ & $\begin{array}{l}0.034 \\
(0.033)\end{array}$ & $\begin{array}{l}0.025 \\
(0.032)\end{array}$ & $\begin{array}{l}0.072^{* *} \\
(0.035)\end{array}$ & $\begin{array}{l}0.060^{*} \\
(0.035)\end{array}$ \\
\hline$\gamma \ln (\mathrm{IPR}) \times \ln (\mathrm{LT})_{i j t}$ & $\begin{array}{l}-0.026^{* *} \\
(0.010)\end{array}$ & $\begin{array}{l}-0.020^{*} \\
(0.010)\end{array}$ & $\begin{array}{l}0.031 \\
(0.026)\end{array}$ & $\begin{array}{l}0.043 \\
(0.026)\end{array}$ & $\begin{array}{l}-0.072 * * * \\
(0.012)\end{array}$ & $\begin{array}{l}-0.068^{* * * *} \\
(0.012)\end{array}$ & $\begin{array}{l}0.022 \\
(0.044)\end{array}$ & $\begin{array}{l}0.038 \\
(0.043)\end{array}$ & $\begin{array}{l}0.044 \\
(0.034)\end{array}$ & $\begin{array}{l}0.048 \\
(0.034)\end{array}$ & $\begin{array}{l}-0.060 * * * \\
(0.015)\end{array}$ & $\begin{array}{l}-0.058 * * * \\
(0.015)\end{array}$ & $\begin{array}{l}-0.079 * * * \\
(0.018)\end{array}$ & $\begin{array}{l}-0.073 * * * \\
(0.018)\end{array}$ \\
\hline$\phi \operatorname{lnRGDP} i t$ & $\begin{array}{l}0.249 * * * \\
(0.064)\end{array}$ & $\begin{array}{l}0.234 * * * \\
(0.064)\end{array}$ & $\begin{array}{l}-0.364 * * \\
(0.157)\end{array}$ & $\begin{array}{l}-0.275^{*} \\
(0.156)\end{array}$ & $\begin{array}{l}0.642^{* * *} \\
(0.074)\end{array}$ & $\begin{array}{l}0.634^{* * * *} \\
(0.074)\end{array}$ & $\begin{array}{l}-0.454^{*} \\
(0.234)\end{array}$ & $\begin{array}{l}-0.427^{*} \\
(0.233)\end{array}$ & $\begin{array}{l}-0.324 \\
(0.200)\end{array}$ & $\begin{array}{l}-0.206 \\
(0.198)\end{array}$ & $\begin{array}{l}0.743^{* * *} \\
(0.119)\end{array}$ & $\begin{array}{l}0.754 * * * \\
(0.119)\end{array}$ & $\begin{array}{l}0.585^{* * *} \\
(0.094)\end{array}$ & $\begin{array}{l}0.565^{* * *} \\
(0.094)\end{array}$ \\
\hline$\phi \operatorname{lnRGDP} i t$ & $\begin{array}{l}0.136 * * * \\
(0.037)\end{array}$ & $\begin{array}{l}0.134 * * * \\
(0.037)\end{array}$ & $\begin{array}{l}0.142 * * * \\
(0.044)\end{array}$ & $\begin{array}{l}0.144 * * * \\
(0.044)\end{array}$ & $\begin{array}{l}0.125 * * \\
(0.061)\end{array}$ & $\begin{array}{l}0.118^{*} \\
(0.061)\end{array}$ & $\begin{array}{l}0.460 * * \\
(0.188)\end{array}$ & $\begin{array}{l}0.495 * * * \\
(0.188)\end{array}$ & $\begin{array}{l}0.126 * * * \\
(0.047)\end{array}$ & $\begin{array}{l}0.124 * * * \\
(0.046)\end{array}$ & $\begin{array}{l}-0.201 \\
(0.238)\end{array}$ & $\begin{array}{l}-0.245 \\
(0.240)\end{array}$ & $\begin{array}{l}0.180 * * * \\
(0.067)\end{array}$ & $\begin{array}{l}0.181 \text { *** } \\
(0.067)\end{array}$ \\
\hline No. of Observations. & 42,050 & 42,504 & 20,925 & 21,187 & 21,125 & 21,317 & 5,944 & 5,944 & 14,981 & 15,243 & 6,847 & 6,847 & 14,278 & 14,470 \\
\hline R-Squared (Within) & 0.803 & $(0.105)$ & 0.848 & $(0.105)$ & 0.758 & $(0.116)$ & 0.870 & $(0.174)$ & 0.811 & $(0.090)$ & 0.814 & $(0.140)$ & 0.718 & $(0.109)$ \\
\hline
\end{tabular}

Notes: *significance at $10 \%$ level, **significance at $5 \%$ level, and $* * *$ significance at $1 \%$ level, respectively. Robust standard errors are in parentheses. The time dummies and constants are included in all specifications even if they are not reported. For lnLT, patents granted abroad in all countries are used as a measure of the level of technology in all the models. 
Table 8. Impacts of LTs and IPRs on Export: Further Robustness Check (Focusing on the Case of the South-to-North)

\begin{tabular}{|c|c|c|c|c|c|c|c|c|}
\hline \multirow{3}{*}{$\begin{array}{l}\text { Dependent } \\
\text { Variable: } \\
\text { lnE }_{\text {ijt (Bilateral Exports) }}\end{array}$} & \multicolumn{4}{|c|}{$\begin{array}{l}\text { 1. High LT Countries among the } \\
\text { South (LT emerging economies) }\end{array}$} & \multicolumn{4}{|c|}{$\begin{array}{l}\text { 2. Lagging the Technology Level } \\
\text { (LT at } t-1 \text { or } t-2 \text { instead of at } t \text { ) }\end{array}$} \\
\hline & \multicolumn{2}{|c|}{20 Highest vs. Others } & \multirow{2}{*}{$\begin{array}{c}\text { BRICs v.s. } \\
\text { (3) }\end{array}$} & \multirow{2}{*}{$\begin{array}{c}\text { Others } \\
(4)\end{array}$} & \multicolumn{2}{|c|}{$L T_{t-1}$} & \multicolumn{2}{|c|}{$L T_{t-2}$} \\
\hline & (1) & (2) & & & (5) & (6) & (7) & (8) \\
\hline $\begin{array}{l}\alpha \ln (\mathrm{IPR})_{j t} \\
\text { (WEF IPR Index of Importers) }\end{array}$ & $\begin{array}{l}0.780^{* *} \\
(0.312)\end{array}$ & $\begin{array}{l}0.265 \\
(0.499)\end{array}$ & $\begin{array}{l}-0.100 \\
(0.371)\end{array}$ & $\begin{array}{l}0.610^{*} \\
(0.328)\end{array}$ & $\begin{array}{l}1.221 * * * \\
(0.334)\end{array}$ & $\begin{array}{l}1.072 * * * \\
(0.340)\end{array}$ & $\begin{array}{l}1.218 * * * \\
(0.332)\end{array}$ & $\begin{array}{l}1.101 * * * \\
(0.338)\end{array}$ \\
\hline $\begin{array}{l}\beta \ln \left(\mathrm{LT}_{\mathrm{ALL}}\right)_{i t} \\
\text { (ALL Foreign Patents) }\end{array}$ & $\begin{array}{l}-0.108 * * * \\
(0.023)\end{array}$ & $\begin{array}{l}-0.004 \\
(0.044)\end{array}$ & $\begin{array}{l}-0.047 \\
(0.197)\end{array}$ & $\begin{array}{l}-0.069 * * * \\
(0.023)\end{array}$ & $\begin{array}{l}1.177 * * * \\
(0.218)\end{array}$ & $\begin{array}{l}0.858 * * * \\
(0.249)\end{array}$ & $\begin{array}{l}1.267 * * * \\
(0.218)\end{array}$ & $\begin{array}{l}0.996 * * * \\
(0.256)\end{array}$ \\
\hline $\begin{array}{l}\gamma \ln (\mathrm{IPR})_{\mathrm{jt}} \mathrm{X} \ln (\mathrm{LT})_{i t} \\
\text { (Interaction between IPR\& LT) }\end{array}$ & $\begin{array}{l}-0.327 * * * \\
(0.080)\end{array}$ & $\begin{array}{l}-0.284 * * \\
(0.137)\end{array}$ & $\begin{array}{l}-0.719 * * * \\
(0.181)\end{array}$ & $\begin{array}{l}-0.255^{* * *} \\
(0.072)\end{array}$ & $\begin{array}{l}-0.283 * * * \\
(0.049)\end{array}$ & $\begin{array}{l}-0.210^{* * * *} \\
(0.057)\end{array}$ & $\begin{array}{l}-0.303 * * * \\
(0.050)\end{array}$ & $\begin{array}{l}-0.241 * * * \\
(0.059)\end{array}$ \\
\hline $\begin{array}{l}\phi \operatorname{lnRGDP}_{i t} \\
\text { (Real GDP of Exporters) }\end{array}$ & $\begin{array}{l}0.643 * * * \\
(0.158)\end{array}$ & $\begin{array}{l}1.105 * * * \\
(0.219)\end{array}$ & $\begin{array}{l}0.418 \\
(0.388)\end{array}$ & $\begin{array}{l}0.742 * * * \\
(0.141)\end{array}$ & $\begin{array}{l}0.706 * * * \\
(0.125)\end{array}$ & $\begin{array}{l}0.697 * * * \\
(0.125)\end{array}$ & $\begin{array}{l}0.674 * * * \\
(0.123)\end{array}$ & $\begin{array}{l}0.665^{* * * *} \\
(0.123)\end{array}$ \\
\hline $\begin{array}{l}\phi \operatorname{lnRGDP}_{i t} \\
\quad \text { (Real GDP of Importers) }\end{array}$ & $\begin{array}{l}-0.220 \\
(0.340)\end{array}$ & $\begin{array}{l}0.708 \\
(0.502)\end{array}$ & $\begin{array}{l}-0.236 \\
(0.433)\end{array}$ & $\begin{array}{l}0.292 \\
(0.335)\end{array}$ & $\begin{array}{l}0.258 \\
(0.302)\end{array}$ & $\begin{array}{l}0.277 \\
(0.300)\end{array}$ & $\begin{array}{l}0.260 \\
(0.302)\end{array}$ & $\begin{array}{l}0.278 \\
(0.300)\end{array}$ \\
\hline Country-fixed effects & & & & & Yes & & Yes & \\
\hline Bilateral-fixed effects & Yes & Yes & Yes & Yes & & Yes & & Yes \\
\hline $\begin{array}{l}\text { No. of Observations. } \\
\text { R-Squared (Within) }\end{array}$ & $\begin{array}{l}2,544 \\
(0.274)\end{array}$ & $\begin{array}{l}2,527 \\
(0.099)\end{array}$ & $\begin{array}{l}528 \\
(0.640)\end{array}$ & $\begin{array}{l}4,543 \\
(0.129)\end{array}$ & $\begin{array}{l}5,071 \\
0.828\end{array}$ & $\begin{array}{l}5,071 \\
(0.153)\end{array}$ & $\begin{array}{l}5,071 \\
0.828\end{array}$ & $\begin{array}{l}5,071 \\
(0.153)\end{array}$ \\
\hline \multirow{4}{*}{$\begin{array}{l}\text { Using various } \\
\text { lnLT measures }\end{array}$} & \multicolumn{4}{|c|}{$\begin{array}{l}\text { 3. Patent Quality Considered } \\
\text { (Trilateral patents \& Patent citations) }\end{array}$} & \multirow{2}{*}{\multicolumn{4}{|c|}{$\begin{array}{l}\text { 4. Alternative Measure for LT } \\
\text { (using EXPY instead of Patent type) } \\
\text { EXPY based on Hausmann et al. (2007) }\end{array}$}} \\
\hline & \multirow{2}{*}{\multicolumn{2}{|c|}{$\begin{array}{l}\text { Trilat }(U S / E P O / J P O) \\
\text { patent as a measure of } L T\end{array}$}} & \multirow{2}{*}{\multicolumn{2}{|c|}{$\begin{array}{l}\text { Average Citation \& } \\
\text { Weighted Citation }\end{array}$}} & & & & \\
\hline & & & & & \multicolumn{2}{|c|}{ World-to-World } & \multicolumn{2}{|c|}{ South-to-North } \\
\hline & (9) & $(10)$ & (11) & $(12)$ & (13) & (14) & $(15)$ & $(16)$ \\
\hline $\begin{array}{l}\alpha \ln (\mathrm{IPR})_{j t} \\
\text { (WEF IPR Index of Importers) }\end{array}$ & $\begin{array}{l}1.259^{* * * *} \\
(0.360)\end{array}$ & $\begin{array}{l}0.976 * * \\
(0.428)\end{array}$ & $\begin{array}{l}1.300^{* * * *} \\
(0.375)\end{array}$ & $\begin{array}{l}1.502 * * * \\
(0.400)\end{array}$ & $\begin{array}{l}12.990^{* * * *} \\
(1.535)\end{array}$ & $\begin{array}{l}11.672 * * * \\
(1.832)\end{array}$ & $\begin{array}{l}24.873 * * * \\
(4.960)\end{array}$ & $\begin{array}{l}22.778 * * * \\
(5.370)\end{array}$ \\
\hline$\underbrace{\beta \ln (\mathrm{LT})_{i t}}_{\text {(Various measures) }}$ & $\begin{array}{l}1.789^{* * *} \\
(0.412)\end{array}$ & $\begin{array}{l}0.926 \\
(0.588)\end{array}$ & $\begin{array}{l}1.540^{* * * *} \\
(0.326)\end{array}$ & $\begin{array}{l}1.317 * * * \\
(0.298)\end{array}$ & $\begin{array}{l}5.935^{* * *} \\
(0.729)\end{array}$ & $\begin{array}{l}5.389 * * * \\
(0.863)\end{array}$ & $\begin{array}{l}11.574 * * * \\
(2.397)\end{array}$ & $\begin{array}{l}10.585^{* * *} \\
(2.601)\end{array}$ \\
\hline$\underset{\text { (Interaction between IPR\& LT) }}{\gamma \ln (\mathrm{IPR})_{\mathrm{jt}} \mathrm{x} \ln (\mathrm{LT})_{i t}}$ & $\begin{array}{l}-0.421 * * * \\
(0.084)\end{array}$ & $\begin{array}{l}-0.230^{*} \\
(0.128)\end{array}$ & $\begin{array}{l}-0.329 * * * \\
(0.073)\end{array}$ & $\begin{array}{l}-0.285^{* * *} \\
(0.068)\end{array}$ & $\begin{array}{l}-1.344 * * * \\
(0.162)\end{array}$ & $\begin{array}{l}-1.202 * * * \\
(0.193)\end{array}$ & $\begin{array}{l}-2.630 * * * \\
(0.533)\end{array}$ & $\begin{array}{l}-2.403 * * * \\
(0.577)\end{array}$ \\
\hline $\begin{array}{l}\phi \operatorname{lnRGDP}_{i t} \\
\text { (Real GDP of Exporters) }\end{array}$ & $\begin{array}{l}0.659 * * * \\
(0.124)\end{array}$ & $\begin{array}{l}0.651 * * * \\
(0.124)\end{array}$ & $\begin{array}{l}0.629 * * * \\
(0.122)\end{array}$ & $\begin{array}{l}0.629 * * * \\
(0.123)\end{array}$ & $\begin{array}{l}0.347 * * * \\
(0.079)\end{array}$ & $\begin{array}{l}0.334 * * * \\
(0.079)\end{array}$ & $\begin{array}{l}0.658 * * * \\
(0.124)\end{array}$ & $\begin{array}{l}0.648 * * * \\
(0.124)\end{array}$ \\
\hline $\begin{array}{l}\phi \ln R G D P \\
\text { (Real GDP of Importers) }\end{array}$ & $\begin{array}{l}0.265 \\
(0.306)\end{array}$ & $\begin{array}{l}0.282 \\
(0.304)\end{array}$ & $\begin{array}{l}0.261 \\
(0.305)\end{array}$ & $\begin{array}{l}0.260 \\
(0.305)\end{array}$ & $\begin{array}{l}0.469 * * * \\
(0.050)\end{array}$ & $\begin{array}{l}0.453 * * * \\
(0.051)\end{array}$ & $\begin{array}{l}0.259 \\
(0.306)\end{array}$ & $\begin{array}{l}0.276 \\
(0.304)\end{array}$ \\
\hline Country-fixed effects & Yes & & Yes & & Yes & & Yes & \\
\hline Bilateral-fixed effects & & Yes & & Yes & & Yes & & Yes \\
\hline No. of Observations. & 5,071 & 5,071 & 21,110 & 21,110 & 21,110 & 21,110 & 5,071 & 5,071 \\
\hline R-Squared (Within) & 0.827 & $(0.146)$ & 0.827 & 0.828 & 0.836 & $(0.137)$ & 0.828 & $(0.152)$ \\
\hline
\end{tabular}

Notes: *significance at $10 \%$ level, **significance at $5 \%$ level, and ***significance at $1 \%$ level, respectively. Robust standard errors are in parentheses. The time dummies, constants and the same gravity control variables in Table 4 are included even if they are not reported. Independent and control variables of Columns (1) to (4) are demeaned for statistical (or graphical) analysis. Column (1) presents the results using the top 20 developing countries in terms of LT: Argentina, Brazil, China, India, Mexico, Poland, Russia, South Africa, Turkey, Ukraine, Malaysia, Bulgaria, Romania, Venezuela, Chile, Panama, Colombia, Thailand, Philippines, and Indonesia. Column (2) presents the results for the remaining 22 developing countries. Columns (3) and (4) present the regression results using the top 4 developing countries in terms of LT: Brazil, Russia, India, and China (BRICs), and the rest of the South, respectively. Columns (5) to (8) use $\mathrm{LT}_{\mathrm{t}-1}$ and $\mathrm{LT}_{\mathrm{t}-2}$ instead of $\mathrm{LT}_{\mathrm{t}}$ to consider the lagged effect of LT. Recall that LT is calculated as the moving average of time $\mathrm{t}$ and $\mathrm{t}-1$. Hence, $\mathrm{LT}_{\mathrm{t}-1}$ is a moving average of $\mathrm{t}-1$ and $\mathrm{t}-2$, and mutatis mutandis for $\mathrm{LT}_{\mathrm{t}-2}$.

Directions of trade flows:

Columns from (1) to (16) are South-to-North (Exporter is a developing country and Importer is a developed country), except for columns (13) and (14) are World-to-World (Exporter and Importer are both all countries). The results of other combinations are available upon request. 
Appendix: Country list (Average values of InLT ${ }_{\text {ALL }}$, InIPR, and High-Tech Exports for $2000 \sim 2007$ )

\begin{tabular}{|c|c|c|c|c|c|c|c|c|}
\hline $\begin{array}{l}\text { Developed } \\
\text { Country (HI) }\end{array}$ & $\operatorname{lnLT} T_{i}$ & $\operatorname{lnIPR}_{j}$ & H.E ${ }^{*}$ & $\begin{array}{l}\text { Developing } \\
\text { Country }\end{array}$ & $\operatorname{lnLT} T_{i}$ & $\operatorname{lnIPR}_{j}$ & H.E & Income \\
\hline Japan & 11.87 & 4.42 & 115.06 & Russia & 6.87 & 3.70 & 4.35 & UMI \\
\hline USA & 11.64 & 4.57 & 188.84 & South Africa & 6.57 & 4.37 & 1.27 & UMI \\
\hline Germany & 11.19 & 4.60 & 119.18 & Brazil & 6.28 & 4.03 & 6.67 & UMI \\
\hline France & 10.21 & 4.53 & 64.73 & Mexico & 5.48 & 4.02 & 31.42 & UMI \\
\hline United Kingdom & 9.92 & 4.57 & 74.63 & Argentina & 5.18 & 3.82 & 0.82 & UMI \\
\hline Rep. of Korea & 9.83 & 4.31 & 70.08 & Poland & 5.02 & 3.98 & 2.01 & UMI \\
\hline Switzerland & 9.67 & 4.57 & 22.84 & Turkey & 4.59 & 3.88 & 1.07 & UMI \\
\hline Netherlands & 9.44 & 4.55 & 54.19 & Malaysia & 4.15 & 4.37 & 52.27 & UMI \\
\hline Sweden & 9.34 & 4.56 & 15.80 & Bulgaria & 3.61 & 3.78 & 0.27 & UMI \\
\hline Italy & 9.31 & 4.22 & 22.72 & Romania & 3.55 & 3.91 & 0.70 & UMI \\
\hline Canada & 9.28 & 4.49 & 26.18 & Venezuela & 3.22 & 3.62 & 0.11 & UMI \\
\hline Finland & 8.70 & 4.57 & 11.73 & Chile & 3.05 & 4.15 & 0.23 & UMI \\
\hline Australia & 8.49 & 4.55 & 3.05 & Panama & 2.89 & 4.12 & 0.00 & UMI \\
\hline Belgium & 8.39 & 4.45 & 19.02 & Colombia & 2.58 & 4.00 & 0.34 & UMI \\
\hline Austria & 8.28 & 4.50 & 11.40 & Latvia & 2.21 & 4.01 & 0.14 & UMI \\
\hline Denmark & 8.25 & 4.59 & 9.18 & Costa Rica & 1.87 & 4.09 & 1.68 & UMI \\
\hline Israel & 8.16 & 4.41 & 5.67 & Uruguay & 1.87 & 4.08 & 0.02 & UMI \\
\hline Spain & 7.67 & 4.30 & 8.68 & Lithuania & 1.65 & 4.00 & 0.39 & UMI \\
\hline Norway & 7.60 & 4.47 & 2.94 & Mauritius & 1.59 & 4.09 & 0.08 & UMI \\
\hline Ireland & 7.00 & 4.43 & 31.04 & Peru & 1.58 & 3.74 & 0.05 & UMI \\
\hline New Zealand & 6.74 & 4.52 & 0.50 & Dominican Rep. & 0.97 & 3.96 & 0.29 & UMI \\
\hline Hungary & 6.17 & 4.21 & 11.46 & Namibia & 0.81 & 4.14 & 0.06 & UMI \\
\hline Singapore & 5.52 & 4.55 & 88.03 & Jamaica & 0.65 & 4.01 & 0.00 & UMI \\
\hline Czech Rep. & 5.49 & 4.10 & 7.52 & China & 7.10 & 4.00 & 156.14 & LMI \\
\hline Greece & 5.06 & 4.20 & 0.88 & India & 6.92 & 4.09 & 2.81 & LMI \\
\hline Hong Kong & 4.83 & 4.44 & 2.77 & Ukraine & 6.27 & 3.74 & 0.90 & LMI \\
\hline Portugal & 4.82 & 4.34 & 2.31 & Thailand & 3.08 & 4.18 & 20.90 & LMI \\
\hline Slovakia & 4.30 & 4.10 & 1.27 & Philippines & 2.83 & 3.83 & 25.38 & LMI \\
\hline Slovenia & 3.66 & 4.28 & 0.72 & Indonesia & 2.59 & 4.01 & 5.41 & LMI \\
\hline Croatia & 3.44 & 3.93 & 0.56 & Morocco & 1.99 & 4.08 & 0.66 & LMI \\
\hline Iceland & 3.35 & 4.53 & 0.16 & Jordan & 1.65 & 4.31 & 0.05 & LMI \\
\hline Estonia & 2.34 & 4.29 & 1.02 & Ecuador & 1.63 & 3.72 & 0.05 & LMI \\
\hline \multirow[t]{10}{*}{ Trinidad \& Tobago } & 0.86 & 3.92 & 0.03 & Sri Lanka & 1.44 & 3.98 & 0.07 & LMI \\
\hline & & & & Tunisia & 1.44 & 4.30 & 0.33 & LMI \\
\hline & & & & Nigeria & 0.86 & 3.83 & 0.01 & LMI \\
\hline & & & & El Salvador & 0.84 & 4.04 & 0.07 & LMI \\
\hline & & & & Guatemala & 0.80 & 3.78 & 0.08 & LMI \\
\hline & & & & Paraguay & 0.36 & 3.54 & 0.01 & LMI \\
\hline & & & & Honduras & 0.30 & 3.82 & 0.01 & LMI \\
\hline & & & & Nicaragua & 0.16 & 3.74 & 0.00 & LMI \\
\hline & & & & Bangladesh & 0.69 & 3.53 & 0.02 & LI \\
\hline & & & & Viet Nam & 0.63 & 3.75 & 0.93 & LI \\
\hline
\end{tabular}

Note: Low-income (LI) economies are those whose Gross National Income (GNI) per capita is less than $\$ 975$. Middle-income economies are those whose GNI per capita is more than $\$ 975$ but less than $\$ 11,906$. LMI (Lower middle-income) and UMI (upper middle-income) economies are separated at a GNI per capita of $\$ 3,855$. HI (High-income) economies are those whose GNI per capita is $\$ 11,906$ or more (World Bank 2010). H.E* indicates average "High-technology Exports" in billion of real dollars during 2000 2007. The 20 highest developing countries in terms of the level of technology are in bold. 
Figure 1: Trend in U.S. International Trade Commission (U.S. ITC) filings on 'Unfair Imports': Increases in IPR-related Litigation in the United States

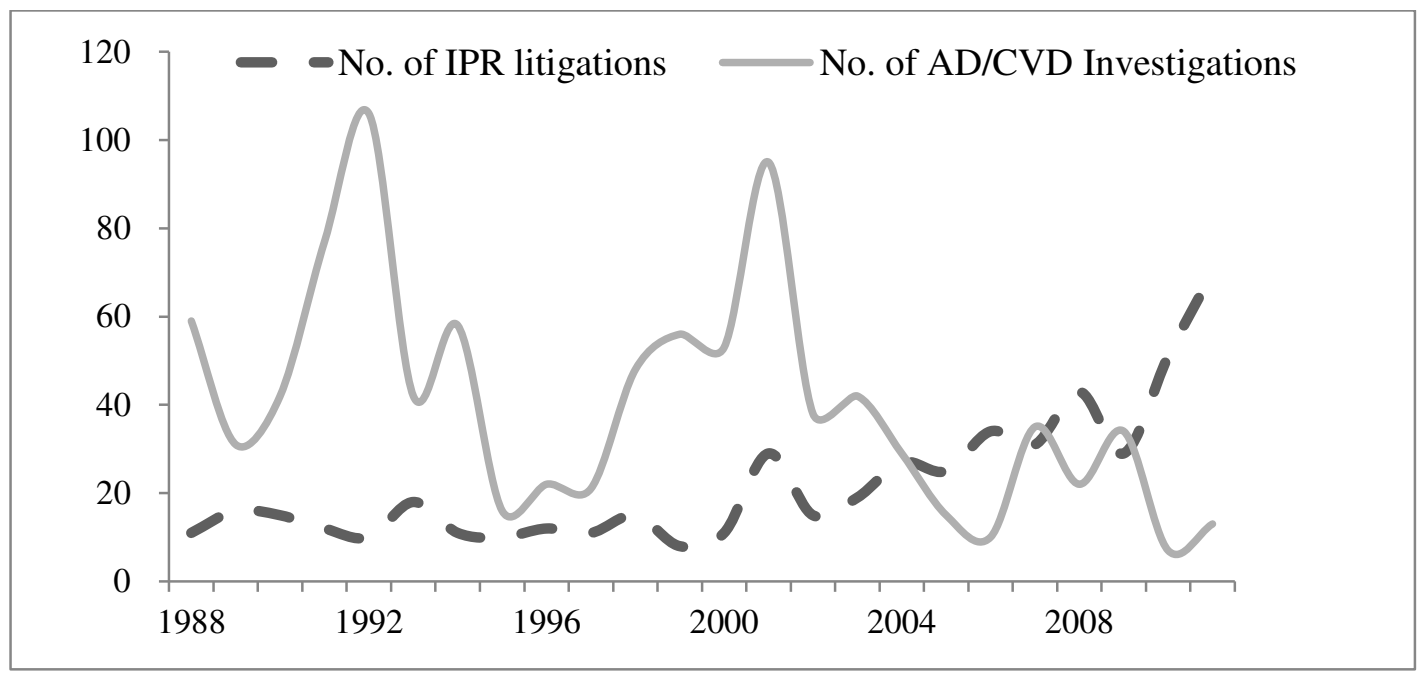

Note: Year refers to September year-end (by fiscal year)

Source: The number of Anti-dumping and Countervailing Duty (AD/CVD) Investigations is compiled from “AD/CVD Investigation: Federal Register History” (http://ia.ita.doc.gov/stats).

The number of ITC litigations is compiled from "Section 337 Statistical Information", the U.S. ITC (www.usitc.gov/press room/337 stats.htm). 
Figure 2A: IPR's Impact on Export dependent on $\ln \left(\mathrm{LT}_{i}\right)$ : Exports from the South to the North

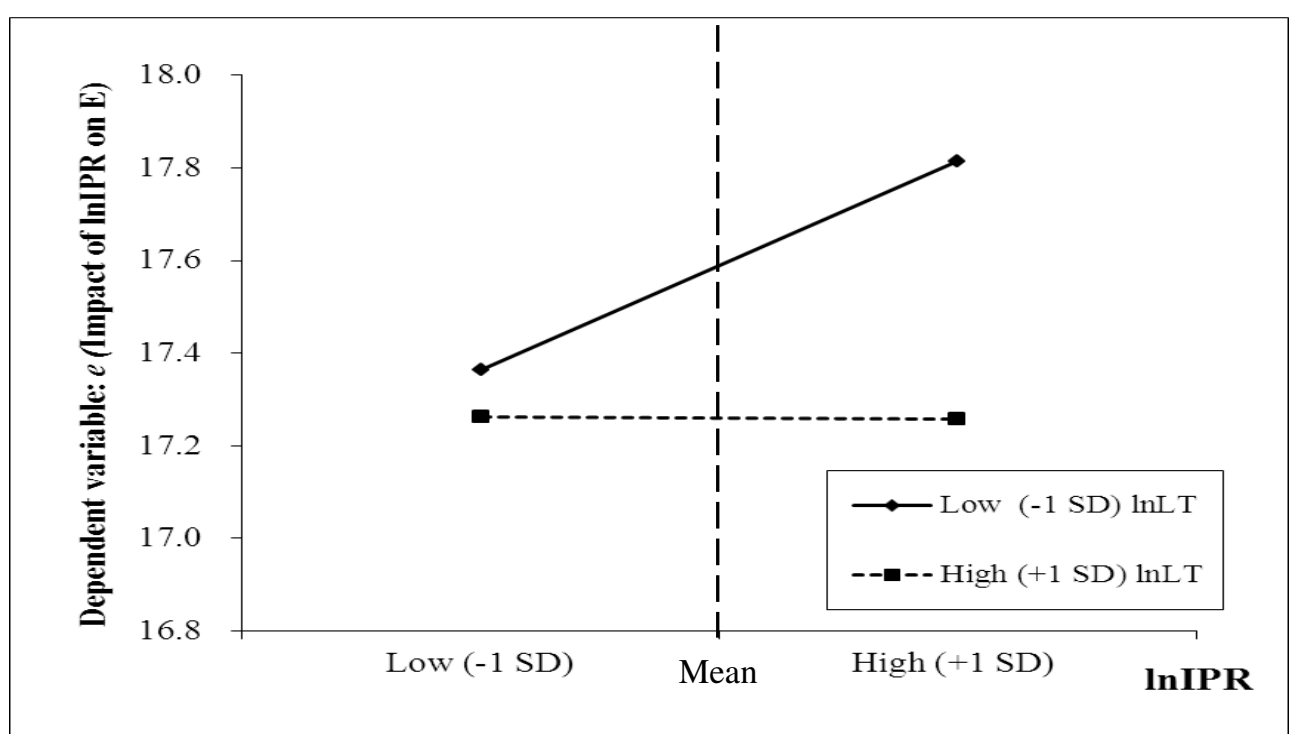

Note: $\mathrm{Y}$ axis $=\hat{e}:$ the estimated elasticity of $\mathrm{E}$ (real exports) with respect to $\mathrm{IPR}_{j}$, calculated as $\% \Delta \mathrm{E}_{i} \approx\left[\alpha+\gamma \ln (\mathrm{LT})_{i}\right] \% \Delta \mathrm{IPR}_{j}$ using the coefficients from column (14) in Table 5.

$\mathrm{X}$ axis $=$ values of IPR such that the low value is mean $-1 S D$ and the high value is mean +1 $S D$.

Figure 2B: LT's Impact on Export dependent on $\ln \left(\mathrm{IPR}_{\mathrm{j}}\right)$ :

Exports from the South to the North

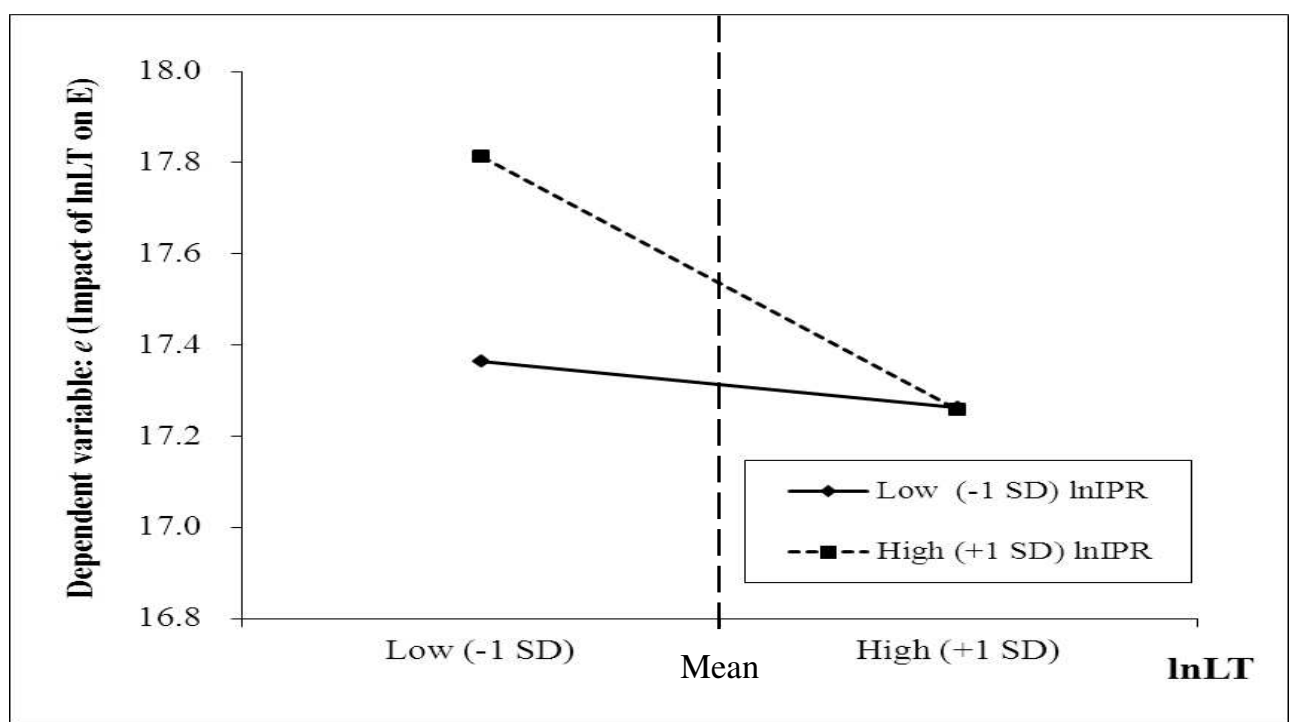

Note: $\mathrm{Y}$ axis $=\hat{e}$ : the estimated elasticity of $\mathrm{E}$ (real exports) with respect to $\mathrm{LT}_{i}$, calculated as $\% \Delta \mathrm{E}_{i j} \approx\left[\beta+\gamma \ln \left(\mathrm{IPR}_{j}\right)\right] \% \Delta \mathrm{LT}_{i}$ using the coefficients from column (14) in Table 5.

$\mathrm{X}$ axis $=$ values of LT such that the low value is mean $-1 S D$ and the high value is mean $+1 S D$. 